\title{
Savannah $\boldsymbol{R}_{\text {iver }}^{\mathrm{PECEVEU}}$
}

OQT

\section{Ecology Laboratory}

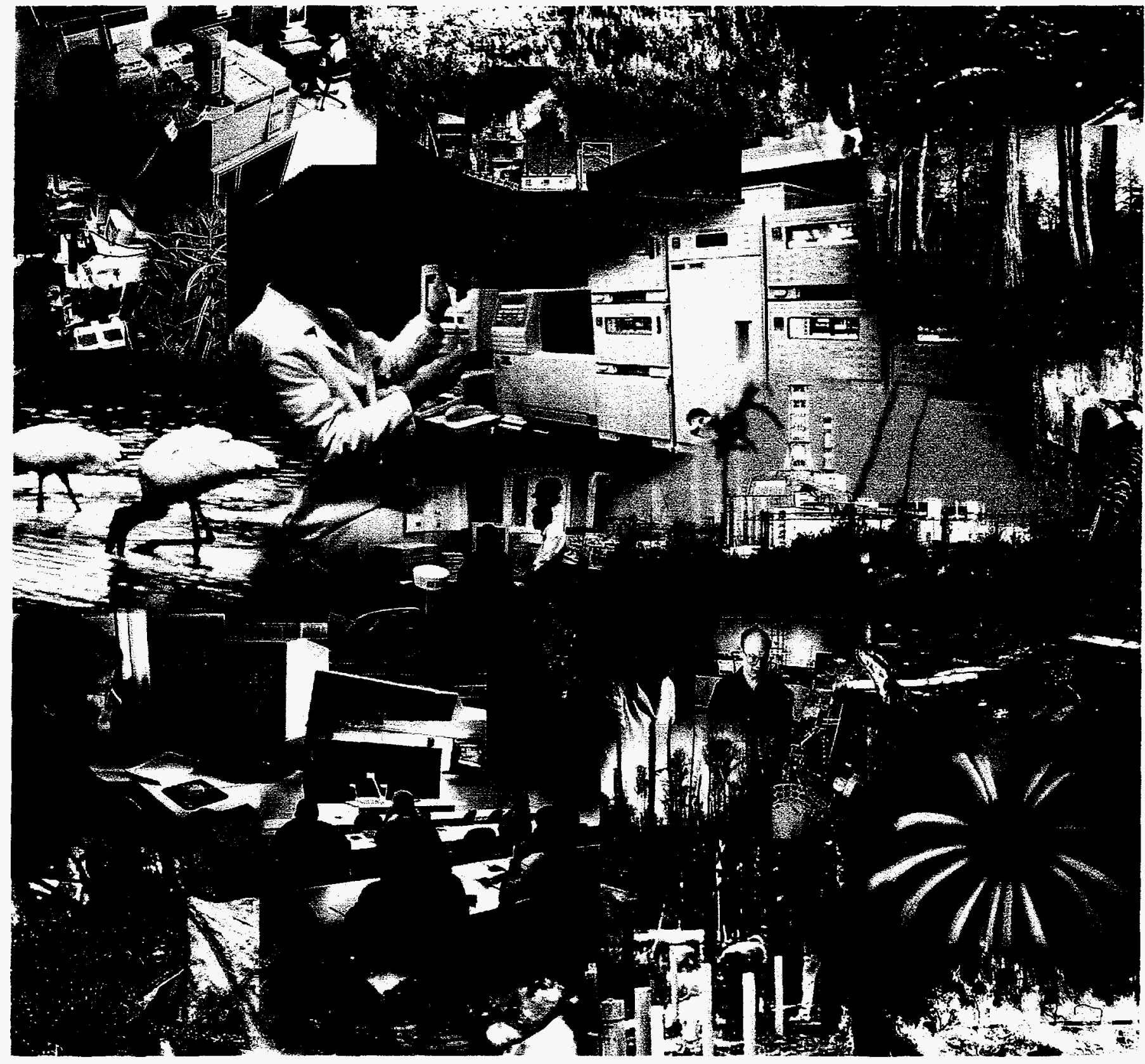

\section{Annual Technical Progress Report}

(II)

The University of Georgia 


$$
\text { SRO--819-29 }
$$

\section{Savannah River Ecology Laboratory}

in $a$

R:

\section{ANNUAL TECHNICAL PROGRESS REPORT \\ OF}

\section{ECOLOGICAL RESEARCH}

SUPPORTED UNDER COOPERATIVE AGREEMENT

DE-F609-96SR18546

BETWEEN THE UNIVERSITY OF GEORGIA

AND THE U.S. DEPARTMENT OF ENERGY

FOR THE YEAR ENDING

JUNE 30, 1998

Michael H. Smith, Director

Prepared by Gary Wein and Brenda $_{\text {Rosier }}$ Savaruah River Ecology Laboratory

Drawer E

Aiken, SC 29801

PH (803) 725-2472 FX 725-3309

E-mail: Wein@SREL.edy

DISTRIBUTION OF THIS DOCUMENT IS UAMUITED 
This report is provided for information only and is not to be considered formally published literature. We request that no citations be made of information contained herein without express consent of the investigator. 


\section{DISCLAMMER}

This report was prepared as an account of work sponsored by an agency of the United States Government. Neitber the United States Government nor any agency thereof, nor any of their employees, makes any warmanty, express or implied, or assumes any legal liability or responsibility for the aceuracy, completeness, or usefulness of any information, apparatus, produch, or process disclosed, or represents that its use would not infringe privately owned rights. Reference berein to any speciñc commercial product, process, or service by trade aame, trademark, inanufacturer, or otherwise does not aecessarily constitute or imply its endorsement, recommendation, or favoring by the United States Government or any ageacy thereof. The views and opinions of authors expressed berein do not becessarily state or reflect those of the United States Government or any agency thereof. 


\section{DISCLAIMER}

Portions of this document may be illegible in electronic image products. Images are produced from the best available original document. 


\section{TABLE OF CONTENTS}

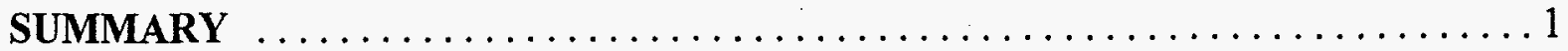
OVERVIEW OF RESEARCH PROGRAMS AND PROGRAM COMPONENTS . . . . 3 ADVANCED ANALYTICAL CENTER FOR ENVIRONMENTAL SCIENCES

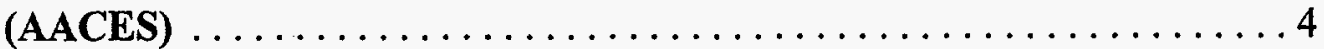

Analytical Applications and Technology Development for the

Characterization of Complex Wasteforms and Environmental

Samples ................................. 5

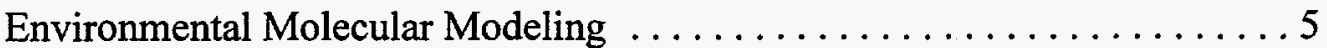

Environmental Remediation and Waste Minimization .............6

Environmental Chemistry and Transport of Contaminants ...........6 6

ECOLOGICAL STEWARDSHIP $\ldots \ldots \ldots \ldots \ldots \ldots \ldots \ldots \ldots \ldots . .6$

Research on SRS Herpotofauna as Bioindicators and Biodetectors of

Environmental Contamination and to Assess the Distribution of

Sensitive Species and Examine Biodiversity Patterns on a Protected

Site $\ldots \ldots \ldots \ldots \ldots \ldots \ldots \ldots \ldots \ldots \ldots \ldots \ldots . \ldots \ldots$

Impact of SRS Clean-up on the Biological and Functional Diversity of

Aquatic Bacteria ............................ 9

Integration of Ecological and Physical Data Sources for Land and Facility

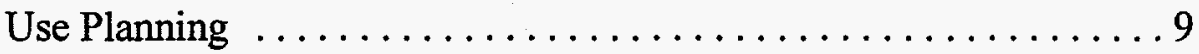

Land Management and Contaminant Movement in SRS Watersheds ..... 10

Recovery of Endangered Plants . ..................... 10

Phytoremediation of Contaminants in Constructed and Natural Wetlands . 11

Restoration Ecology of Highly Impacted Forested Floodplain Ecosystems 11

Restoration of Longleaf Pine Communities . ............... 12

Wetland Restoration and Ecosystem Sustainability ............. 13

ECOTOXICOLOGY, REMEDIATION, AND RISK ASSESSMENT

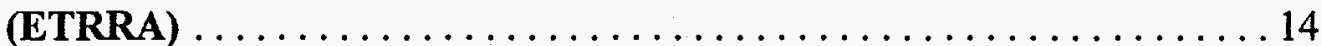

Cycling of Mercury in SRS Waters and Accumulation by Fish ........ 15

Compliance-Associated Monitoring and Risk Assessment for the

Endangered Wood Stork ....................... 15

Ecotoxicology: Environmental Physiology of Sublethal Effects of Trace

Element Contamination on Organisms on the SRS $\ldots \ldots \ldots \ldots 16$

Improved Quantitative Methods $\ldots \ldots \ldots \ldots \ldots \ldots \ldots \ldots \ldots \ldots$

Phytoremediation: Plant-Based Technologies To Remediate Contaminated

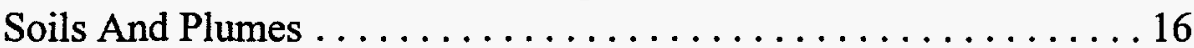

Risk Assessment of Mixed Waste: Synergistic Effects on Individuals and

Populations ............................... 17

Studies of the Fate and Effects of Nuclear Industrial Contaminants in

Wildlife of the DOE Savannah River Site: Assessments of

Ecological and Human Health Risks . . . . . . . . . . . . . 18

Aquatic Invertebrates and Trophic Pathways for Contaminants in Pond 4, A

Small Abandoned Cooling Reservoir on the SRS . . . . . . . 18

RADIOECOLOGY ................................ 19

Dose Assessments for Plants and Animals Exposed to Environmental

Radiation .............................. 20 
Environmental Distribution, Uptake, and Transport of Radioactive Contaminants on the Savannah River Site: Meeting DOE Needs for Compliance and Predictions of Risk . . . . . . . . . . . 20

International Programs in Radioecology $\ldots \ldots \ldots \ldots \ldots \ldots \ldots \ldots \ldots \ldots \ldots$

Genetic Changes in Response to Previous and Current Plant Operations . . 21

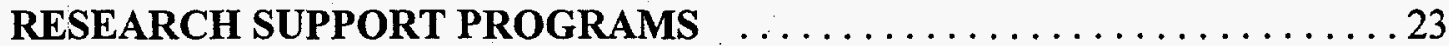

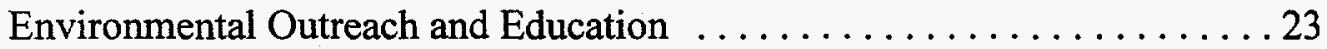

National Environmental Research Park Program . . . . . . . . . . . . 24

DOE Research Set-Aside Areas . . . . . . . . . . . . . . . . . 25

SREL Undergraduate and Graduate Education Program . . . . . . . . . 27

Research Data Archive Activities . . . . . . . . . . . . . . . 30

Environmental Health and Safety Program ............... 31

Quality Assurance Program . . . . . . . . . . . . . . . . . . 31

SPECIAL ACCOMPLISHMENTS OF FACULTY, STAFF, STUDENTS AND

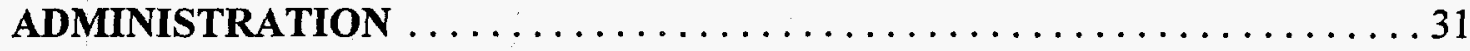

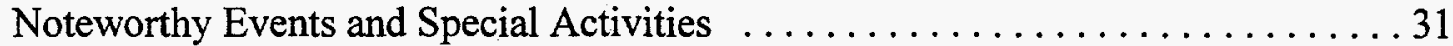

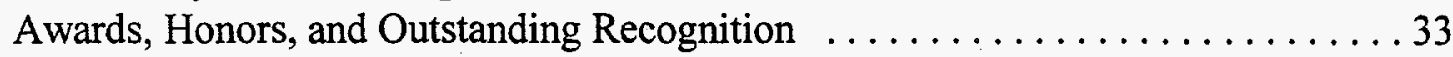

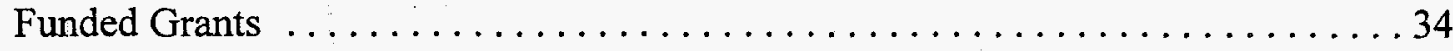

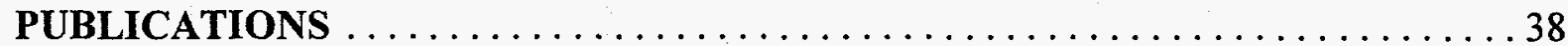

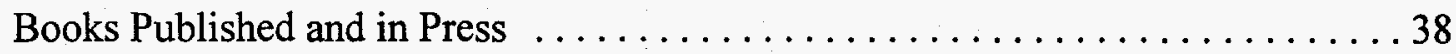

Journal Articles and Book Chapters Published $\ldots \ldots \ldots \ldots \ldots \ldots \ldots \ldots \ldots$

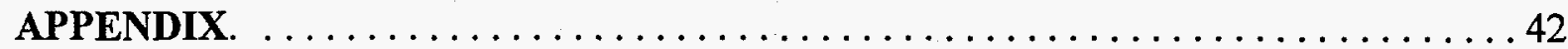

Figure 1. Organizational Chart, Savannah River Ecology Laboratory . . . . . . . 42 


\section{SUMMARY}

The Savannah River Ecology Laboratory (SREL) is a research unit of the University of Georgia (UGA). The overall mission of the Laboratory is to acquire and communicate knowledge of ecological processes and principles. SREL conducts fundamental and applied ecological research, as well as education and outreach programs, under a Cooperative Agreement with the U.S. Department of Energy (DOE) at the Savannah River Site (SRS) near Aiken, South Carolina.

The Laboratory's research mission was fulfilled with the publication of four books and 95 journal articles and book chapters by faculty, technical staff, students, and visiting scientists. An additional 110 journal articles have been submitted or are in press. Researchers archived 30 data sets into the SREL Data Archive System. Several other noteworthy events took place as faculty members received awards and conducted conferences. These are elaborated upon in the Noteworthy Events section.

Notable scientific accomplishments include work conducted on copepod systematics, molecular modeling, and synthesis of research in risk assessment and radioecology.

- Dr. Barbara E. Taylor and colleague Adrienne E. DeBiase, have described, Aglaodiaptomus atomicus, a new species of copepod collected in freshwater, temporary wetlands called Carolina bays. (Proc. Biol. Soc. Wash. 110:569-580).

- Dr. Brian J. Teppen and others developed a new approach for performing molecular dynamic modeling of clay minerals (J. Phys. Chem. 101:1579-1587). Molecular-scale models, combined with experimental studies of clay mineral-soil solution interfaces, can significantly improve our understanding of contaminant transport in the environment.

- Drs. Michael C. Newman and Carl L. Strojan are coeditors of a recently-published book by Ann Arbor Press titled "Risk Assessment: Logic and Measurement" that is based on a symposium held at the SREL Conference Center. This workshop brought together recognized experts to formulate logical and quantitative methods for ecological and human risk assessment.

- Research conducted by Dr. Tom G. Hinton and others indicate that a 10-year effective half-time for radiocesium in Pond $\mathrm{B}$, an abandoned cooling reservoir, is considerably less than the original 28 -year estimate ( $J$. Environ. Radioactivity 37:251-268). The difference was attributable to a decrease in the sediment inventory, which accounts for nearly all of the radionuclides in Pond $\mathrm{B}$.

SREL scientists have been involved with research at Chernobyl and other sites in the Former Soviet Union (FSU) since 1992 and have fostered excellent working relationships with foreign scientists and administrators. Our efforts to strengthen working relationships with the scientists at Chernobyl have been realized by a recent invitation to establish a joint International Radioecology Laboratory within the confines of the Chernobyl Exclusion Zone. A
Government to Government Agreement was signed 22 July 1998 to establish the International Radioecology Laboratory at Chernobyl, Ukraine by Vice President Gore and Ukrainian President Kuchma at their recent summit. This laboratory will provide researchers from the Former Soviet Union (FSU), Europe, and the United States with capabilities to perform field studies in the highly contaminated regions of the Chernobyl Zone and to analyze samples in a cost-efficient and coordinated manner.

Researchers at SREL currently have funding from 38 grants in addition to funding provided by DOE-SR. Sources of grants awards range from state agencies such as Georgia and South Carolina Departments of Natural Resources to federal agencies such as the U.S. Fish and Wildlife Service and the National Park Service. SREL is particularly proud of the recent Natural and Accelerated Remediation Program (NABIR) grant received by Paul M. Bertsch for his proposal "Microbial Reduction and Immobilization of Uranium in Fe (III)- and Mn (IV)- Containing Sediments " Researchers from SREL have also been awarded two grants by the U.S. DOE Office of Energy Research and Environmental Management: Paul Bertsch's "Mineral Surface Processes Responsible for the Decreased Retardation (or Enhanced Mobilization) of ${ }^{137} \mathrm{Cs}$ from High Level Waste Tank Discharges Proposal and Thomas G. Hinton's "Determining Significant Endpoints for Ecological Risk Analyses."

The Savannah River Ecology Laboratory played a pivotal role in the development of the DOE's Environmental Centers of Excellence Program at the Savannah River Site. These centers include the National Water Research Center, the Soil Remediation Research Center, and the International Initiative in Radioecology. Membership in these centers includes the Savannah River Ecology Laboratory (SREL), Education, Research and Development Association (ERDA), and South Carolina Universities Research and Education Foundation (SCUREF) Universities. Seven collaborative research projects were initiated this year by SREL with funding from this program. During this first year, new staff were hired, experimental facilities were constructed, and experiments were begun. Awards over three years total more than $\$ 3$ million for these seven grants.

The final report of the Scientific Review of the Savannah River Ecology Laboratory was received on August 1, 1997. "The panel was highly supportive and complimentary of SREL's excellent research record, its response to the needs of the SRS, and its accomplishments in education and outreach over an extended period of time." The panel made several general recommendations that would help SREL to respond to the changing needs and missions of the DOE.

In order to compensate for changing DOE mission needs and faculty attrition, a search was initiated in the fall of 1997 for two new faculty members in two of the following four areas: environmental microbiology, surface water hydrology, molecular ecological genetics, and/or environmental microbiology. A total of eight candidates were invited to present seminars and meet with the SREL faculty in the spring of 1998. Based on these interviews, positions have been offered to Dr. Travis Glenn of the University of South Carolina and Dr. Betsy Sutherland from Brookhaven 
National Laboratory. Dr. Glenn has accepted one position and will start with SREL in the fall of 1998. Negotiations are ongoing with Dr. Sutherland.

Participants in the SREL Education Program during 1997 and 1998 came from schools located throughout the United States and included 13 undergraduate students and 34 graduate students. These participants came from more than 17 states, emphasizing the national stature of the SREL program. In the past year two graduate students from the SREL earned Masters Degrees and five earned Doctor of Philosophy Degrees. The SREL was awarded a National Science Foundation grant from the Research Experiences for Undergraduates Program for a proposal titled "The Impact of Energy Technologies on Natural Environmental Systems," in April 1997.

In addition to holding faculty positions in 11 departments at the University of Georgia, various SREL faculty have adjunct status at 15 other colleges and universities. Faculty, staff and students also are active in providing outreach and service to the scientific community. Representatives from the SREL hold more than 40 editorial or committee positions in national groups and organizations and also serve on several UGA academic and administrative committees. Over 70 lectures, scientific presentations, and posters were presented during the past year at colleges and universities, including minority institutions.

The SREL Outreach and Education Program reaches a different audience in its successful efforts to communicate scientific awareness to the general public. In 1997-1998, Outreach staff gave 211 lectures, 35 tours, 10 exhibits, and 28 workshops to schools, civic groups, and similar audiences, reaching more than 70,000 people. A book produced by the SREL Outreach Program, "The Snakes of Georgia and South Carolina," was released to the public in May, 1998. The book was produced by SREL researchers and received additional funding from the Georgia Forestry Commission, U.S. Forest Service, Georgia Department of Natural Resources, The State Museum, South Carolina Parks and Recreation, and Fort Discovery, as well as DOE. The booklet has been submitted to the Southeastern Outdoor Press Association (SEOPA) for award consideration. In addition to this publication, the Outreach Program sponsored a Donnelly Workshop. This project trains teachers to take their students to a new level in environmental education. The workshop focused on biological diversity and the tools to prepare outdoor field labs for students. The workshops are funded by a grant from the Donnelly Foundation. Dr. J. Whitfield Gibbons won first place in the SEOPA "Best Radio" contest for his program on frog calls and second place for "Best Article" for his piece on the Okefenokee Swamp.

The Distance Learning Facility (DLF) continues developing its programs and courses this year. Specifically, the DLF will co-sponsor a master's degree in Health Physics and a Nuclear Criticality Certificate program with Georgia Institute of Technology. In addition to this degree program the DLF was used to broadcast programs developed by SREL faculty that supplemented science curriculums to nine high schools in the state of Georgia.
The Conference Center has continued to see wide use, both by the SREL, and the local community. The facility was used to host a total of 108 scientific meetings and environmental education programs for students, teachers and the general public this past year. Initial plans for a greenhouse renovation and Plant and Soil Processing Facility have been developed. This project's $\$ 1$ million FY '97 construction budget has been postponed until FY ' 99 by DOE funding delays. A request for construction funds has been submitted in the FY ' 99 budget.

Representatives of the Laboratory also serve local and statewide communities by organizing a can-goods drive, managing a recycling program, participating generously in the UGA Campaign for Charities, and hosting an annual auction benefitting the South Carolina Chapter of The Nature Conservancy. 


\section{OVERVIEW OF RESEARCH PROGRAMS AND PROGRAM COMPONENTS}

During FY '97 SREL reorganized its programs and established four new research groups of investigation building both on past experience of the former Divisions of Biogeochemical Ecology, Wetlands Ecology, and Wildife Ecology and Toxicology and on current DOE-SR research needs. Within each of the four groups new programs are being developed to be implemented in $F Y$ '99. Because expediency is needed to meet rapidly changing DOE needs, SREL researchers began initiating these new programs in FY' 98 . Fiscal Year '98 represents a transition year into FY' 99 programs. Program descriptions of the four new research groups can be found at the beginning of research group report section. 


\section{ADVANCED ANALYTICAL CENTER FOR ENVIRONMENTAL SCIENCES (AACES)}

Advanced analytical and spectroscopic techniques provide an opportunity to generate new scientific knowledge needed for developing novel waste isolation and stabilization technologies, as well as cost-effective remediation strategies. Application of these advanced methods can provide scientifically-defensible data to support risk-assessment-based remediation strategies that involve in situ stabilization or no remedial action, both of which should significantly reduce costs. Included in the diverse array of advanced instrumentation being applied to analyze complex environmental samples and elucidate fundamental processes are: nuclear magnetic resonance spectroscopy, synchrotron $X$-ray absorption spectroscopy, accelerator mass spectrometry, ion cyclotron resonance mass spectrometry, atomic force microscopy, and solid-state tunable laser spectroscopy.

$A A C E S$ is organized around three interactive research programs in:

- Environmental chemistry/hydrogeochemistry

- Analytical applications and technology development

- Environmental computational chemistry

AACES objectives are to:

- Serve as an advanced research and development facility with a primary interest in bridging basic and applied environmental research from the molecular to ecosystems level;

- $\quad$ Establish the infrastructure to provide regional and national users from industry, government, and universities with both the expertise and advanced methods required to generate a better understanding of contaminant behavior in the environment, elucidate molecular mechanisms of toxicity, develop better, cheaper and more environmentally-sound remediation approaches; and

- $\quad$ Provide a mechanism for the further development, modification and application of advanced analytical and spectroscopic techniques to better understand complex environmental processes. 
Analytical Applications and Technology Development for the Characterization of Complex Wasteforms and Environmental

\section{Samples}

Principal Investigators: Drs. Paul M. Bertsch, Douglas B. Hunter, Gary L. Mills, Christopher S. Romanek, John C. Seaman, and Brian J. Teppen

The remediation and restoration of contaminated sites throughout the U.S. Department of Energy (DOE) weapons complex presents formidable problems due to the diversity and complexity of both the waste mixtures and subsurface environmental matrices. Scientifically sound characterization, remediation, and performance assessment technologies that are cost-effective and provide acceptable risks to humans and ecosystems are needed to achieve regulatory objectives and to fulfill DOE's waste management and cleanup goals. The successful development and implementation of these technologies requires knowledge of the chemical speciation, spatial distribution, reactivity, transformation reactions, geochemical mobility, and bioavailability of contaminants at the atomic and molecular scales which can be used to interpret and predict contaminant behavior at microscopic, macroscopic, and field scales. The various research programs within the Advanced Analytical Center for Environmental Sciences (AACES) address these issues by employing an integrated, multidisciplinary, multiscale approach to studies at the interface between basic and applied environmental research. The Analytical Applications and Technology Development Program focusing on the development and applications of advanced analytical techniques for the molecular scale characterization of complex wasteforms and environmental samples is a cornerstone component of the research efforts within AACES. Using an array of "state-of-the-science" analytical instruments and technologies the program has developed and applied novel and innovative methods to acquire the molecular scale measurements that are prerequisite to conducting studies within the Environmental Chemistry and Transport, Remediation and Waste Minimization, and Computational Chemistry programs within AACES and other programs at SREL.

- An analysis of year 2000 compliance on all instrumentation was completed and upgrade strategies were implemented for all instrumentation to be year 2000 compliant by mid 1999. Currently, more than $80 \%$ of instrumentation is in compliance.

- An automated microscope stage was added to the fluorescence microscope and chemical imaging was developed on existing micro-spectroscopic software. These additions have been in support of projects at F-Area and D-Area groundwater plumes and the Tims Branch/Steed Pond system dealing with metal, metalloid, and radionuclide fate and transport, and remediation of contaminated soils.

- Software was developed for control of a time-resolved luminescence compartment through existing tuneable laser and boxcar integrator systems. Hardware was recently purchased for single photon counting capabilities and the control software will be developed in FY '99. These upgrades are supporting research efforts on source term identification and evaluation of remediation strategies for $\mathrm{U}$ and $\mathrm{Ni}$ in Steed Pond and DOE-Natural and Accelerated Bioremediation Research and Office of Biological and Environmental Research (OBER) funded projects.

- The installation and commissioning of the Fourier Transform Mass Spectrometer (FT-MS) system has progressed and should be completed early in FY ' 99 . The FT-MS will be used to support studies examining the fate and transport of contaminant organics, such as trichloroethylene (TCE), perchloroethylene (PCE), and polycyclic aromatic hydrocarbons and remediation of organic contaminated soils and groundwater. Projects dealing with the fate of triethyl phosphate (TEP) in enhanced bioremediation of TCE/PCE contaminated groundwater and diesel contaminated soils in R-Area and C-Area will also be supported.

\section{Environmental Molecular Modeling}

\section{Principal Investigator: Dr. Brian J. Teppen}

The Environmental Molecular Modeling program investigates chemical reactions at the atomic-scale that determine contaminant fate and transport. Since all environmental processes are the sums of myriad atomic-scale events, no fundamental understanding is possible without this perspective. In this sense, we view molecular modeling as a complementary enhancement to experimental spectroscopic, diffraction, and imaging technologies that are other strengths of the Advanced Analytical Center for Environmental Sciences (AACES). Our research currently focuses on the modeling of important colloidal phases found in soils and sediments and their interactions with contaminants in aqueous solution.

Theoretical tools at our disposal include both quantum mechanics and empirical molecular modeling. Using quantum mechanics, we have performed some of the largest and most precise calculations pertinent to soil minerals. Using empirical molecular modeling, our efforts range from state-of-the-art parameter development to simulations of complex, practical systems.

The specific objectives of the Environmental Molecular Modeling program are to (a) determine TCE and PCE partitioning behavior in the deep subsurface aquifer materials of the Savannah River Site (SRS) in order to reevaluate plume mobility, (b) collaborate with the Savannah River Technology Center (SRTC) in an effort to develop and test protocols to more efficiently characterize the tritium burden of contaminated building materials on the SRS, (c) provide a fundamental computational context in which experimental investigations of mineral redox-based remediation technologies may be interpreted and generalized, and (d) develop new molecular modeling methodologies that will allow computational chemistry to be applied by many more researchers involved in DOE cleanup missions. 
- We are using molecular dynamics simulations to explore mechanisms by which soil minerals might remove TCE from solution and tightly bind it. Our modeling supports certain hypotheses in the literature that may have major implications for the assessment of risks associated with TCE migration in the deep subsurface such as the large $\mathrm{A} / \mathrm{M}$-Area plume.

- Computational studies of cesium-montmorillonite clay interactions show a mechanism of adsorption that has not yet been proposed, but that qualitatively agrees with the best experimental data available. Quantitative comparisons of our simulations with experiments are in progress and are in support of current remediation efforts in the Savannah River Lab basins of A-Area.

- Quantum mechanics are being used to study the oxidation-reduction process in Fe-rich clay minerals in order to determine the differences in electron density. The results help to explain a number of experimentally observed phenomena and provide some mechanistic insight into Fe-redox processes at mineral surfaces.

\section{Environmental Remediation and Waste Minimization}

Principal Investigators: Drs. Domy C. Adriano, Paul M. Bertsch, Gary L. Mills, Christopher S. Romanek, and John C. Seaman

The operation of the U.S. Department of Energy (DOE) weapons complex over the past forty years has resulted in a diverse array of environmental problems that involve the chemical contamination of surficial and subsurface materials. These contaminants include both stable elements and radionuclides in a variety of inorganic and organic compounds, including reactive metals (e.g., $\mathrm{Ni}, \mathrm{Al}, \mathrm{Cr}, \mathrm{Cu}$, $\mathrm{Cd}, \mathrm{Zn}, \mathrm{As}, \mathrm{U}, \mathrm{Cs}$ ), organometallic compounds (e.g., $\mathrm{Hg}-$ and Se-bearing components), and organic chemicals (e.g., L-NAPLS, volatile chlorinated hydrocarbons), polychlorinated biphenyls (PCB) and polycyclic aromatic hydrocarbons (PAH). These contaminants can be found together in complex associations of mixed waste at many sites, and pose significant human and ecological health risks.

These contaminants must be removed from the environment or transformed into benign substances through active or passive remediation efforts. Scientists participating in the Environmental Remediation and Waste Minimization Program at the SREL focus interdisciplinary research efforts on the characterization of the state, fate, and source of environmental contaminants, the identification of processes and mechanisms of remediation, and the development of methods for waste minimization that reduce the cost of clean-up at contaminated sites throughout the DOE complex.

- Shallow groundwater near the M-Area Seepage Basin contains inorganic chloride that is derived from either degraded halogenated organic solvents (e.g., TCE) or is naturally derived. Isotopic markers $\left({ }^{37} \mathrm{Cl} /{ }^{35} \mathrm{Cl}\right)$ have been used by SREL to differentiate between these sources for the first time.

- The varying contribution of low $\mathrm{pH}$, metal-rich runoff in the D-Area Coal Pile Retention Basin to groundwater at $\mathrm{D}$-Area was determined using the distinct isotopic signatures $\left({ }^{2} \mathrm{H} /{ }^{1} \mathrm{H},{ }^{18} \mathrm{O} /{ }^{16} \mathrm{O}\right)$ of basin water and local meteoric recharge.

- A viable alternative management strategy to disposing of coal fly-ash in basins is land application of ash/sewage sludge mixtures, such as for the turf grass industry. Such disposal strategies are being evaluated for the reclamation of highly eroded land to ameliorate soil-water-plant conditions while monitoring environmental impacts.

- The Tims Branch/Steed Pond system received more than $45 \mathrm{MT}$ of $U$ and large quantities of other metals, such as $\mathrm{Ni}, \mathrm{Cu}, \mathrm{Cr}, \mathrm{Al}$, and $\mathrm{Pb}$. Initial results suggest that a combination of in situ immobilization and phytostabilization is a viable remediation strategy for this system which can effectively reduce environmental risk and provide significant cost savings.

- In situ remediation of $\mathrm{Cr}$ contaminated aquifers can be achieved using ferrous iron [i.e. Fe(II)] containing solutions; however, several potential adverse effects of such a reclamation technique were identified in pilot-scale studies that must be addressed before it is applied in the field.

- Chlorinated solvents (e.g., PCE, TCE) are both prevalent subsurface contaminants and difficult to clean up. Results from batch studies and dynamic column experiments demonstrate the feasibility of PCE degradation (via reductive dechlorination) in groundwater by chemical reduction of redox-sensitive metals associated with SRS-aquifer sediments.

\section{Environmental Chemistry and Transport of Contaminants}

Principal Investigators: Drs. Paul M. Bertsch, Douglas B. Hunter, Gary L. Mills, and John C. Seaman

The legacy of nuclear materials production and processing for the manufacturing of nuclear weapons has resulted in significant quantities of contaminant metals, such as $\mathrm{U}, \mathrm{Ni}$, $\mathrm{Cr}$, and $\mathrm{Cu}$, and lesser quantities of a number of longer lived radionuclides (i.e., ${ }^{90} \mathrm{Sr}$ and ${ }^{137} \mathrm{Cs}$ ) and transuranics, as well as a wide range of contaminant organics, being introduced into soils and sediments throughout the U.S. Department of Energy complex. Chemical speciation and/or contaminant mineral-surface interactions are the primary parameters controlling transport, bioavailability, and toxicity of metals, metalloids, and radionuclides from wasteforms and within the environment. The subsurface migration of contaminants and contaminant mixtures within complex heterogeneous geologic systems is also controlled by various reactive mineral and organic components. A more complete understanding of chemical species distributions and transformations and of the importance of physicochemical, mineralogical, and biogeochemical controls is required to accurately predict contaminant migration, evaluate environmental risk, and design cost effective, yet environmentally sound remediation strategies.

This research effort is designed to: (1) determine the chemical speciation of metals, metalloids, radionuclides, and contaminant organics in a range of wasteforms and Savannah 
River Site (SRS) environs by standard and novel wet chemical and advanced spectroscopic techniques; (2) evaluate the biogeochemical dynamics of these contaminants as influenced by natural processes and various chemical and biological remediation strategies; (3) perform detailed physicochemical characterization of the Coastal Plain soils and aquifer sediments on the SRS and identify critical mineral surface/contaminant interactions; (4) determine the static contaminant partitioning/extraction as a function of local solution conditions (i.e., groundwater chemistry, contamination events, etc.) and soil/aquifer mineralogy; and to (5) conduct intermediate/field-scale, dynamic transport studies which are analogous to the kinetically controlled conditions experienced in the field to identify the mechanisms controlling the natural attenuation of contaminants and the impact of various proposed remediation/reclamation strategies.

- Chemical speciation studies of $\mathrm{U}$ and $\mathrm{Ni}$ in Steed Pond sediments have suggested that a large fraction of these metals in the sediments are in chemically labile forms and potentially bioavailable. Studies using various stabilization agents suggest that chemical speciation of the $U$ and $\mathrm{Ni}$ can be changed to less labile forms via in situ immobilization.

- Phytoaccumulated Se and $\mathrm{Cr}$ in different plant species from D-Area basins are translocated and stored differently, and phytoaccumulators can detoxify $\mathrm{Cr}$ through reduction processes.

- Reduction of $\mathrm{Cr}$ via interaction with reduced $\mathrm{Fe}$ phases has been evaluated as a potential in situ remediation strategy for contaminated groundwater (e.g., D- and FAreas). Detailed chemical speciation of reduced $\mathrm{Cr}$ phases by $\mathrm{X}$-ray absorption spectroscopy and by high resolution thermogravimetric analyses reveals that, depending on the treatment regime, the reduced $\mathrm{Cr}$ can be surface sorbed, precipitated as a $\mathrm{Cr}(\mathrm{OH})_{3}$ phase, or as a mixed $\mathrm{Cr} / \mathrm{Fe}$-oxyhydroxide. The $\mathrm{Cr} / \mathrm{Fe}$-oxyhydroxide is four-orders-of-magnitude less soluble than the other phases and therefore has reduced mobility.

- The subsurface transport of nonionic organic contaminants (e.g., diesel hydrocarbons) is controlled by sorption reactions with components of the aquifer sediments such as natural organic carbon and the mineral phase components. Studies using dynamic column transport experiments have shown that composition of natural carbon affects contaminant transport and that literature sorption constants (Koc) may be inappropriate for accurately modeling transport in SRS groundwaters. 


\section{ECOLOGICAL STEWARDSHIP}

Most (90\%) of the Savannah River Site (SRS) is not industrialized or directly contaminated. These lands nevertheless are susceptible to various ecological risks. For example, management practices such as timber harvest, maintenance of power line rights-of-way, management of wildlife populations, or placement and operation of new facilities create potential risk because they can reduce biological or landscape diversity, increase unwanted organisms, or threaten rare or desirable taxa. Moreover, these management practices may affect movement of various chemicals in areas that are contaminated. For example, timber harvesting may increase nitrogen run-off from uplands and result in higher ammonium levels in adjacent floodplain soils. Ammonium can displace radiocesium from clay sediments and cause increased downstream movement of cesium. Furthermore, decommissioning of facilities will also have an effect on the landscape. Management of SRS lands requires data-intensive research and monitoring that provides meaningful land stewardship recommendations to minimize ecological risk and promote ecosystem health. This program includes research relevant to ecological land management and stewardship, and provides advice to U.S. Department of Energy (DOE) on management of the SRS using concepts such as ecological integrity and risk assessment. The focus is to examine effects of land use patterns on abiotic and biotic resources in watersheds; on the communities, populations, and individuals within them (with an emphasis on rare species and those with localized distribution); and on restoration of degraded and contaminated systems.

Ecological Stewardship Research Program studies will:

- Assess the current status of degraded and less altered ecological systems;

- Conduct research to restore damaged systems;

- Conduct research relevant to site remediation, such as phytoremediation of contaminated wetlands and forest management to reduce movement of contaminants within watersheds; and

- Develop recommendations for ecologically sound management.

The Ecological Stewardship Program will interface with SRS management professionals to:

- Participate in decision-making activities and issue-related task groups by bringing our knowledge base to the table;

- Develop a system to better inform SRS managers about ecological issues and our knowledge base;

- Increase transfer of ecosystem management technologies to SRS, other DOE facilities, and other land management agencies; and

- Interface with other SREL groups, SRS groups, and professionals from other DOE sites to develop workshops that explore and establish new approaches to land use and ecological risk assessment. 
Research on SRS Herpotofauna as

Bioindicators and Biodetectors of Environmental Contamination and

to Assess the Distribution of

Sensitive Species and Examine

Biodiversity Patterns on a

Protected Site

\section{Principal Investigator: Dr. J. Whitfield Gibbons}

The southeastern United States has the highest biodiversity and abundance of reptile and amphibian species in North America. Because of the rich herpetofaunal biodiversity on the U.S. Department of Energy's (DOE) Savannah River Site (SRS), this public land area has been the focus of extensive inventory and research since 1951 and has become the most prolific single site for herpetological research in the world. The SRS is the largest tract of land in North America for which herpetofaunal species of abundance, distribution, and diversity have been measured on a long-term basis, resulting in the documentation of more species of herpetofauna $(1,000,000+$ individuals of $100+$ species $)$ than have been reported from any other public land area in the United States.

The goal of current studies is to continue to capitalize on this enormous data base and herpetological experience by supplementing previously collected information with studies designed to enhance DOE's environmental commitment, involving issues as diverse as documenting responses (e.g., mutations) of organisms to local contamination, determining distribution and abundance of sensitive species that have potential for regulations that could restrict site activities, and establishing the extent of dispersal of organisms from radioactively or chemically contaminated sites. All of these projects have been natural extensions of an original goal of documenting the SRS as one of the most highly diverse tracts of land in the Upper Coastal Plain as a consequence of long-term environmental protection of native habitats.

We recommend based on a long-standing program of ecological research on the SRS and of a familiarity with environmental concerns at the national level, that all activities on the SRS, especially facility development and forestry activities, be carefully assessed in terms of both short- and long-term environmental impact. A thorough environmental research program that is in concert with the environmental alterations necessary on the SRS will result in responsible environmental management, both actual and perceived. Studies in this program cover the amphibians and reptiles, two major vertebrate groups found on the SRS. Our monitoring of natural fluctuations in herpetofaunal populations continues to provide the baselines that are critical for fulfilling DOE's objectives of remediation of animal populations on the SRS.

- SREL has documented that the SRS has a higher herpetofaunal biodiversity than any other public land area in the United States, thus confirming DOE as a responsible land steward of the NERP.
- By continuing to find radioactive turtles on the SRS, SREL contributes to DOE's intention of locating all potentially hazardous sites and monitoring any potential biohazards.

\section{Impact of SRS Clean-up on the Biological and Functional Diversity of Aquatic Bacteria}

\section{Principal Investigator: Dr. J Vaun McArthur}

Bacteria are involved in all ecosystem level processes including but not limited to nutrient cycling and organic matter decomposition. Microbial processes are the primary mechanisms used for in situ remediation of contaminated sites. It is not clear what the chronic effect of contamination is on bacterial populations and/or functional diversity. Studies in this program seek to detail the effects of various contaminants on the biological and functional diversity of bacteria in surface waters on the Savannah River Site (SRS). Results of these studies will provide information on the ability of natural populations to respond to the contaminants and provide an indication of the length of time required for recovery of biological and functional diversity following clean-up.

- Sediment samples from Four Mile Branch were collected every $200 \mathrm{~m}$ from the delta to Road 4. These samples have been screened for antibiotic resistance against four different antibodies. Resistance to all four antibiotics increased significantly immediately below the confluence of the stream draining $C$ - Area and Central Shops. These data suggest that water from this stream is under very different selection regimes than the Four Mile main channel (i.e., different environmental challenges). In addition these data indicate the power and importance of collecting spatially explicit data.

- Environmental DNA have been extracted from each of the Four Mile Branch sediment samples and are being screened to determine the distribution of soluble methane monooxygenase genes. These genes are used by bacteria capable of digesting methane. They are also some of the genes that fortuitously breakdown organic contaminants such as TCE.

\section{Integration of Ecological and Physical Data Sources for Land and Facility Use Planning}

\section{Principal Investigator: Dr. John Pinder}

An integrated, two-part research program is in progress to coordinate the execution of Implementing Actions EQ1.4.1.8 and EQ1.4.1.10. The research involves: (1) remote sensing analyses of satellite and airborne data to quantify SRS habitats and patterns of habitat change; and (2) the development of a site-wide database that will combine existing physical data with SREL's extensive biological data in a format that will support rapid decision making processes 
in planning and risk assessments. This format will be a raster database composed of $100-\mathrm{m}$ by $100-\mathrm{m}$ grid cells that may be implemented using simple, desktop or laptop computers and commercially available, industry-standard software.

The principal research objective during FY' 98 has been the development of a digital habitat map of the SRS in a format that supports ecological risk assessment. This habitat map was developed from a combination of Landsat Thematic Mapper satellite data to identify major habitat types (e.g., open-canopy pine forest, closed-canopy pine forest, evergreen hardwoods, sparse herbaceous plant cover) and the refinement of these categories using the current forest management plan of the Savannah River Natural Resource Management and Research Institute. Combining the satellite data and the forest management plan produces a highresolution analysis of habitat types that contains more detail than either of the component data sources. This map was prepared in paper and digital formats using $30-\mathrm{m}$ by $30-\mathrm{m}$ grid cells in ARCVIEW format and was submitted to Westinghouse Savannah River Company - Environmental Restoration (WSRC-ER) for their comments and approval before the final map version was released for general site use. Research is continuing to: (1) produce a more general habitat map that includes the SRS and the surrounding 100$\mathrm{km}$ by $100-\mathrm{km}$ area that may be used for off-site dose computation and reconstruction; and (2) produce similar habitat maps for 1988 and 1992 that may be used to evaluate the effects of site operations on habitat changes and degradations.

- Release of a 1997 digital habitat map of the Savannah River Site for use in ecological risk assessments.

\section{Land Management and Contaminant Movement in SRS Watersheds}

Principal Investigators: Drs. Beverly S. Collins, J Vaun McArthur, Christopher S. Romanek, Rebecca R. Sharitz, Barbara E. Taylor, and Thomas G. Hinton

This program is a large-scale, multidisciplinary study of the potential effects of SRS land use on radiocesium $\left({ }^{137} \mathrm{Cs}\right)$ mobility in streams draining Savannah River Site (SRS) watersheds. Specifically, we propose to determine the effects of different forms and quantities of nitrogen on ${ }^{137} \mathrm{Cs}$ mobility in SRS streams, and the potential for continued or increased off-site movement of ${ }^{137} \mathrm{Cs}$. Forest management such as clearcutting, burning, and herbiciding can affect nitrogen cycling and movement from uplands to floodplains. It is known that ammonium $\left(\mathrm{NH}_{4}+\right)$ will displace ${ }^{137} \mathrm{Cs}$ from clay minerals and organic colloids, thus activities that increase $\mathrm{NH}_{4}+$ levels in contaminated floodplain sediments have the potential for increasing the mobility of ${ }^{137} \mathrm{Cs}$ in these fluvial systems. The initial focus will be on ${ }^{137} \mathrm{Cs}$ levels and mobility in the Lower Three Runs (LTR) watershed.

- A proposal was submitted to the NABIR program on "Microbially-mediated transformation reactions and ${ }^{137}$ Cs mobility in Lower Three Runs Creek."
- Two proposals were submitted to BechtelEnvironmental Restoration Division: "Sampling Design and Survey of ${ }^{137} \mathrm{Cs}$ in the Lower Three Runs Creek Operable Unit" and "Potential Enhancement of Radiocesium Mobility in the Lower Three Runs Creek Operable Unit."

\section{Recovery of Endangered Plants}

\section{Principal Investigators: Drs. Philip M. Dixon and Beverly S.} Collins

This project will develop methods to enhance recovery of two plant species of special concern on the Savannah River Site (SRS). The most important species is the smooth purple coneflower, Echinacea laevigata, which occurs in two populations on the SRS. Echinacea is Federally Endangered, and is listed as a sensitive species by the U.S. Forest Service. These designations require the DOE to avoid actions with deleterious impacts to the populations. The other species to be examined, sandhill lily, Nolina georgiana, is also listed as sensitive by the U. S. Forest Service. Populations of both species are exposed to threats, including powerline maintenance activities and accidental herbicide application, and management activities, including forest thinning and burning. This project will continue demographic monitoring of the two SRS populations of smooth coneflower and selected populations of the sandhill lily. It will investigate methods for transplanting threatened populations to suitable non-threatened sites. Finally, it will test effects of alternative management practices on research populations established from seeds. This project collaborates with and complements Savannah River Natural Resources and Research Institute (SRI) programs for rare and endangered species; results will be provided to SRI for incorporation in species management plans.

- Nolina georgiana seeds had $70 \%$ germination in the greenhouse.

- Nolina georgiana seedlings planted on a forestedge-clearcut transition had $93 \%$ survival after two weeks, with no difference in survival among zones. Herbicide application four weeks after outplanting reduced survival to $63 \%$ in the clearcut, $60 \%$ in the edge, and $67 \%$ in the forest. After six weeks, survival was $6 \%$ in the clearcut, $13 \%$ in the edge, and $26 \%$ in the forest.

- Echinacea individuals at the Road B-9 population are difficult to monitor because of repeated disturbance to the population, including vehicle traffic and accidental fire.

- The Echinacea Burma Road population continues a slow decline, but decline is not as rapid as reported last year. Some of the individuals not found last year have reappeared. Corrected 1996 population size is $150 ; 137$ individuals were alive in 1997.

- The wet spring of 1998 seems to have been good for Echinacea. Seedlings and small plants were observed in early summer 1998. This is the first time in a few years that new individuals have been documented. Summer 1998 census is expected to show a much reduced decline or even an increase in population size. 


\section{Phytoremediation of Contaminants in Constructed and Natural Wetlands}

Principal Investigators: Drs. J Vaun McArthur, Kenneth W. McLeod, and Beverly S. Collins

Some wetlands and surface waters at the Savannah River Site (SRS) and at other U.S. Department of Energy (DOE) sites are contaminated with a mixture of chemical pollutants, including pesticides, volatile organic compounds, metals, acids, and radionuclides. Current cleanup technologies are time consuming and too expensive. Therefore, it is necessary to develop technologies to stabilize and contain contaminants in situ.

Plants can play a major role in remediating and rehabilitating wetlands. Various plant species have been shown to stabilize, filter and/or extract excess nutrients, organic solvents, PAHS, TNT residues, metals, and radionuclides. Evapotranspiration by the plants also will minimize leaching of contaminants to the groundwater by reducing the amount of downward water movement. Plant architecture provides favorable microenvironments for fungi and microorganisms to biodegrade toxic organic compounds and may further provide nutrients for these microorganisms. Plant-based remediation could be adopted in situations where contamination level is low, risk to the public is low, and where slower, low-cost cleanup can be substituted for an immediate and high-cost cleanup.

Program objectives are: (1) to investigate the tolerance and uptake rates of contaminants by various native wetland species; (2) characterize the microbial assemblages associated with each native plant species; (3) determine what combinations of plants/microbial assemblages best degrade contaminants; and (4) determine the feasibility of using nitrogen isotope ratios as indicators of nitrogen source in wetland plants.

- When growing in common flooded soil conditions, leaf concentrations of manganese in water tupelo (Nyssa aquatica) were generally higher than in baldcypress (Taxodium distichum) and were positively correlated with soil manganese concentrations.

- Increased soil manganese concentrations decreased height, diameter, and stem, leaf, and total biomass of water tupelo, but not of bald cypress.

- Excess soil cobalt does not reduce biomass production of swamp tupelo (Nyssa slyvatica), water tupelo, or baldcypress; both Nyssa species leaves accumulate 10 to 100 times more cobalt than baldcypress with no toxicity symptoms.

- Since flood-tolerant species have specific adaptations to persist in anoxic habitats, these species may also possess characteristics to absorb contaminants from wetlands. As flooded soil becomes anoxic, soil manganese becomes more available, potentially reaching toxic levels. Plant species that persist in flooded soils must cope with high manganese concentrations. In flooded soils, leaf manganese concentrations of bald cypress were not as high as in water tupelo leaves, but the biomass of bald cypress was not reduced at higher soil manganese concentrations like it was for water tupelo. Therefore, the overall extraction of manganese from flooded soils by baldcypress may exceed that of water tupelo. In contrast, water tupelo and swamp tupelo absorb much more cobalt than baldcypress and would be more appropriate to remediate a high cobalt-containing soil.

- Salvinia plants grown in water from natural Carolina bays or farm ponds had significantly higher condition than plants grown in water from the D-Area coal runoff basin, as indicated by chlorophyll and pheophytin concentrations.

- Plants grown in D-Area basin water had 10 to 100 times higher concentrations of zinc, chromium, cadmium, copper, aluminum, iron, and nickel than did the plants grown in uncontaminated waters.

- Microbial assemblages on the surface of plants in the D-Area water were different from those growing on plants in the uncontaminated waters at the end of the experiment but not at start-up.

- Floating aquatic plants can remove metals from solution and accumulate them in their tissues. This may be facilitated by the bacterial assemblages growing on their surfaces.

\section{Restoration Ecology of Highly Impacted Forested Floodplain Ecosystems}

Principal Investigators: Drs. J Vaun McArthur, Kenneth W. McLeod and Rebecca R. Sharitz

Three of the five major streams that drain the Savannah River Site (SRS) were severely impacted by thermal effluents from reactor operations. Although, reactor operations ceased and natural succession is occurring, these ecosystems remain different from unimpacted reference systems. This research proposes to investigate, through experimental and observational studies, improved methods for the restoration of under- represented and severely disturbed habitats on the SRS. Emphases has been on the recovery of wetland woody vegetation and establishment of macroinvertebrate communities similar to undisturbed reference systems. Our research has the following specific objectives:

- Determine whether these ecosystems have a balanced indigenous community.

- Determine the effect of various large-scale restoration practices on the recovery trajectories of these ecosystems.

- Experimentally determine "best" restoration strategies for specific biotic components of the system.

\section{$\underline{\text { Plants }}$}

- Growth and survival of baldcypress (Taxodium distichum), water tupelo (Nyssa aquatica), willow oak (Quercus phellos), nuttall oak ( $Q$. nuttallii), overcup oak ( $Q$. lyrata), and cherrybark oak ( $Q$. falcata var. 
pagodaefolia) were not affected by controlling the competing vegetation by either mowing or spraying with "Accord" herbicide.

- All of the species in this experiment except $Q$. falcata var. pagodaefolia were successfully established.

- Planting elevation was much more influential in affecting survival and growth than the competition control methods.

- Not mowing or herbiciding competing vegetation would result in considerable cost savings in a restoration program such as that in conducted in Fourmile Branch or Pen Branch.

\section{Invertebrates}

- No differences were found among the experimental sections in the numbers and types of aquatic invertebrates.

- Differences were observed between the upper reaches of Pen Branch and the lower experimental reaches in the types and abundance of macroinvertebrates.

- Significant differences, including hydrology, still exist between unimpacted control streams (e.g., Meyers Branch) and Pen Branch.

- Treatments designed to speed recovery of riparian zones along the highly impacted Pen Branch corridor have not been effective in returning instream communities to predisturbance conditions. Restoration of this stream system will require either significantly longer time frames or further manipulations that restore stream structure and subsequent function.

\section{Restoration of Longleaf Pine Communities}

\section{Principal Investigators: Drs. Kenneth W. McLeod and} Beverly S. Collins

Longleaf pine-dominated communities are unique and under- represented in the southeastern United States. Vast areas of this community type have been converted to agriculture or silviculture, urbanized, or seriously impacted by other anthropogenic activities (e.g., suppression of fire). Undisturbed examples of these community types are almost nonexistent. Reduction of this habitat type has limited several plant and animal species to the point of requiring federal protection (e.g., red-cockaded woodpecker, gopher tortoise, indigo snake). Restoration of this community type will provide habitat for the protected 'species and increase the diversity of plant communities on the Savannah River Site (SRS).

Fire, water and nutrients are all important environmental factors in regulating the species composition of longleaf pine-dominated communities. Sandy soils do not retain water or nutrients very well and both of these factors are potentially limiting. Patchy, uneven distribution of these resources leads to patchy vegetation and promotes clonal species. Dryness also contributes to the high natural frequency of fire to which these species are adapted. Thus, fire promotes the continuation of the community and protection from fire allows less fire-adapted species to invade. As environmental factors such as soil type, slope, and aspect vary, longleaf pine shares dominance with hardwood species. In dry environments, longleaf pine shares dominance with several drought-tolerant oak species.

This research program conducts studies specific to these communities and the individual species found in these communities. Knowledge of this nature is essential for proper land management and restoration of the underrepresented longleaf pine-dominated communities. During the past year, three research projects have examined: (1) the relative photosynthetic production and water relations of three oak species during typical summer conditions; (2) the response of three common sandhills grasses to spatially heterogeneous nutrient peaks in the soil after fires; and (3) the response of the most common clonal shrub, blueberry (Vaccinium stamineum), to fire.

\section{Ecophysiology of scrub oaks}

- As soil moisture declined during the summer months, turkey oak (Quercus laevis) was consistently less water stressed than the other species, both following nightly recharge of water into the trees and at midday when maximum evaporative demand existed. Scrubby post oak ( $Q$. margaretta) trees did not recharge with water as fully as turkey oak and did not have strong control over water loss. Bluejack oak ( $Q$. incana) recharged the least overnight but had better control over water loss during the day than did scrubby post oak.

- These different hydration conditions among oak species did not produce different photosynthetic rates.

- Management activities in longleaf pine-turkey oak communities that alter soil moisture status will differentially affect the oak species and could be used to shift the relative composition of oak species.

Biomass allocation of three Sandhill grasses with spatially different nutrient regimes.

- The spatial pattern of soil nutrients did not affect root or shoot biomass of Andropogon virginicus, while Sorghastrum elliottii shoots had marginally greater biomass when the soil nutrients were evenly distributed, and Aristida stricta roots had greater biomass with clumped soil nutrients.

- In all species, above and below ground biomass differed between high and low soil fertility.

- Nutrient inputs into soil as a result of fire will enhance grass growth, but only $A$. stricta roots track soil nutrient heterogeneity.

\section{Vaccinium genetics and response to fire}

- Vaccinium stamineum clumps average, 1.833 genotypes per clump, with $50 \%$ of all clumps having $>1$ genotype and $25 \%$ of all clumps having $>2$ genotypes.

- V. stamineum clumps were, on average, 1.2 times their pre-burn size following a late summer burn (range 0.11 - 16.6). Size increase was solely through vegetative sprouting.

- Although fire changes the size of $V$. stamineum clumps, it is unlikely that burning creates multigenotype aggregates by breaking up larger clumps. 
- The understory diversity of the longleaf pine community is, in part, a function of the genetic and spatial diversity of the vegetation. Restoration practices that encourage diversity should incorporate Vaccinium clump structure and genetic diversity.

\section{Wetland Restoration and Ecosystem Sustainability}

Principal Investigators: Drs. Rebecca R. Sharitz, Barbara E. Taylor, and Beverly S. Collins

About $90 \%$ of the wetlands that exist on Department of Energy (DOE) lands occur on the Savannah River Site (SRS). Many of these wetlands have been functionally altered by SRS industrial or land management activities or by previous land owners. The DOE is committed to restoring disturbed wetlands to mitigate wetland losses and demonstrate good land management practices. This program seeks to determine the most cost-effective and successful methods for restoring hydrologically altered wetland depressions (Carolina bays) on the SRS. Specific objectives are: (1) to evaluate bay restoration treatments that represent realistic land management options for the SRS; (2) to determine if wetlands under restoration are moving toward appropriate abiotic and biotic endpoints as determined from intact or reference wetlands; and (3) to assess functional differences among land management alternatives and develop predictions of how these alternatives may provide suitable habitat for key plant and animal species. The SRS has numerous Carolina bays, many of which were hydrologically altered and/or converted to agriculture or forestry by land owners prior to 1950. Results of a preliminary study by SREL of one bay suggest that wetland hydrology can be restored by closing drainage ditches. Restoration of wetland vegetation depends on factors such as availability of propagules in the soil seedbank and dispersal of desirable wetland species into the wetlands. The extent to which other wetland ecosystem functions can be restored and whether these functions can be maintained through activities consistent with forest management practices on the SRS requires further assessment.

- Preliminary research suggests that typical hydrologic conditions may be restored within 2-4 years to some Carolina bays by closing drainage ditches.

- Some wetland plant species remain in the seedbank of drained Carolina bay wetlands for $40+$ years and may contribute to wetland recovery if appropriate hydrologic conditions are restored. This may be a cost-effective way to initiate functional restoration.

- A larger set of drained Carolina bays has been chosen for replicated study of wetland restoration processes and recovery trajectories. 


\section{ECOTOXICOLOGY, REMEDIATION, AND RISK ASSESSMENT (ETRRA)}

With DOE's need to clean up the accumulated contaminants from more than 40 years of operation, information about the fate and effects of these contaminants and effective strategies for cleanup are needed. The ETRRA Group conducts research on ecotoxicology and remediation, interfaces with SRS environmental management and risk assessment professionals, and develops and holds workshops and short courses on ecotoxicology and remediation.

ETRRA's research activities include:

- Fate and effect studies of contaminants at all levels of ecological organization.

- Evaluation of the effectiveness of remediation activities.

- $\quad$ Studies relevant to SRS environmental professionals, including risk assessors.

- Generation of ecological and ecotoxicological baseline data.

- Development and application of new methods for assessing impact, risk, and recovery.

ETRRA interfaces with SRS management and remediation professionals by:

- $\quad$ Supporting environmental management and risk assessment activities.

- Integrating and synthesizing SREL information applicable to SRS environmental management and risk assessment.

- $\quad$ Providing scientific and technical expertise in ecological and toxicological fields.

ETRRA communicates with SRS and other environmental professionals by:

- Developing workshops and short courses for training personnel, and by promoting interactions between SRS professionals and outside experts.

- Writing and editing books and documents on ecotoxicology, remediation, and risk assessment, which contribute knowledge relevant to SRS and other DOE site activities.

- $\quad$ Publishing high-quality research relevant to SRS goals in peer-reviewed journals.

- $\quad$ Presenting research findings at local, national, and international forums. 


\section{Cycling of Mercury in SRS Waters and Accumulation by Fish}

\section{Principal Investigators: Drs. Charles H. Jagoe and I. L Brisbin, Jr.}

This program supports Savannah River Site (SRS) regulatory compliance and ecological risk assessment needs by producing information on the behavior of mercury and trace metals in SRS reservoirs and other waters. Particular emphasis is placed on uptake and accumulation of mercury by fish and other organisms, and the factors controlling these processes. This program is closely integrated with Compliance-Associated Monitoring and Risk Assessment for the Endangered Wood Stork Program and Studies of the Effects of Nuclear Industrial Contaminants Upon Wildlife: Predictions of Risk Program. It provides mercury data for the dietary intake by sensitive piscivorous wildlife. However, this program differs from the others by focusing on the basic mechanisms by which mercury enters food webs. These mechanisms depend on processes of methylation and demethylation that occur in soils and waters. Methylmercury is the only mercury species that accumulates in food webs. Factors controlling mercury speciation include water chemistry, changes in water level, and flooding and drying of soils. Previous work has indicated increased mercury concentrations in gamefish as a result of the Par Pond refill, and provided preliminary data on mercury in organisms living in Carolina Bays. SRS activities involving the future of L-Lake or other reservoirs, or Carolina Bay restoration may also alter mercury bioavailability, raising regulatory compliance issues involving the U.S. Environmental Protection Agency (EPA) and Fish and Wildlife Service (FWS), as well as risk assessment issues. This program documents mercury and selected trace metals in fish and other biota over time, and identifies the key watershed processes that control accumulation of metals in biota so that land-management impacts can be minimized. Data generated under this program supports compliance with state and federal regulations concerning allowable mercury burdens in fish and wildlife.

- Seasonal samples of largemouth bass and other gamefish from L-Lake and Par Pond show that most bass 12 inches in length exceed the U.S. Food and Drug Administration's limit of one ppm mercury in fish for human consumption. Mercury could pose a threat to consumers if these fish were released offsite, or public access for fishing was permitted.

- Detectable mercury concentrations have been found in all fish from approximately 10 SRS Carolina Bays surveyed. Mean concentrations from several of these bays exceed guidelines for prey items for sensitive avian species.

- The likely source of mercury to these bays is atmospheric deposition, as they are not located near SRS industrial facilities, and have not received water from the Savannah River.

- Elevated mercury concentrations have been found in other aquatic vertebrates on SRS, including bullfrogs, alligators, and banded water snakes. These organisms accumulate mercury via their diet of fish. Effects of mercury on these species are largely unknown, but high levels of mercury can influence behavior or impair reproduction in pisciverous wildlife.

\section{Compliance-Associated Monitoring and Risk Assessment for the Endangered Wood Stork}

\section{Principal Investigators: Drs. I. Lehr Brisbin, Jr. and Charles H. Jagoe}

This program meets the U.S. Department of Energy's (DOE) compliance needs for the federally endangered wood stork (Mycteria americana), as mandated by the Section 7 consultation between DOE and the U.S. Fish and Wildlife Service (FWS). These compliance needs are met by monitoring the Savannah River Site (SRS) for the frequency and location of stork use and by determining contaminant concentrations (primarily mercury) in stork prey. Monitoring efforts focus on active, historical, and potential SRS stork foraging sites (typically Carolina bays and other bay-like wetlands), including reservoir systems potentially impacted by the proposed SRS River Water System Shutdown project. Most "natural" SRS wetlands are not surveyed for contaminants by other site monitoring programs, and this project provides comparisons of mercury concentrations in small reservoir fish with similar-sized fish in wetlands (bays) not thought to receive direct (point-source) pollution. Local stork colonies will be monitored for observable contaminant effects and will be a source of tissues to analyze for contaminant detection. Contaminant levels (mercury) in nestlings from these local stork colonies will also be compared to levels in nestlings from more distant colonies.

The Kathwood mitigation ponds continue to be operated as per an agreement between DOE and FWS, and were monitored to insure that the FWS compliance requirements were met. This facility also functioned as a field laboratory determining the variables that affect prey consumption rates of storks. Data from these combined efforts allows for the assessment of environmental risks, associated with past, present, or proposed site activities to wood storks foraging on the SRS.

New studies are being considered with a captive population of a surrogate wading bird species (white ibis, Eudicimus albus). These would document the behavioral and physiological effects associated with different levels of exposure to dietary mercury. Critical information needed to assess risk which frequently is not available. These studies also would allow the determination of the relationships between dietary exposure and tissue mercury burdens in wood storks. Such research could re-write regulatory guidelines concerning mercury and wildlife and possibly reduce DOE compliance needs with regard to mercury contamination.

- Wood storks use in 1997 of SRS wetlands was relatively low, due to severe drought conditions that resulted in the complete drying of many of the Site's ephemeral wetlands typically used by storks as foraging sites. As expected, wood storks did not use the 
reservoir systems, which were at or near full pool throughout the year.

- Blood and feather down were collected from stork nestlings from one local and three distant colonies and analyzed for mercury levels. Nestlings from the local colony (Chew Mill Pond in Jenkins Co., GA) had the highest concentrations of mercury. Two of the distant colonies were coastal, where saltwater prey diets tend to have lower mercury intake.

- Wood Stork use of the Kathwood mitigation ponds was monitored in 1997 and documented the continued use of this facility by large numbers $(>100)$ of storks.

\section{Ecotoxicology: Environmental Physiology of Sublethal Effects of Trace Element Contamination on Organisms on the SRS}

\section{Principal Investigator: Dr. Justin D. Congdon}

Coal combustion accounts for $90 \%$ of fossil fuel-related wastes produced in the U.S. and constitutes a major category of waste production on the Savannah River Site (SRS). In $\mathrm{D}$-Area, coal ash is discharged into open settling basins that are located approximately one quarter mile from the Savannah River. Effluent from the basins enters Beaver Dam Creek which provides an aquatic corridor to the river. High levels of trace element contamination ( $\mathrm{As}, \mathrm{Hg}, \mathrm{Cr}, \mathrm{Cd}, \mathrm{Se}$ ) exist in the water, sediments, and biota in the settling basins and downstream areas. Body burdens of contaminants in some organisms are orders of magnitude greater than Environmental Protection Agency (EPA) limits for humans. Among the organisms that have been documented to be contaminated by trace elements are alligators, softshell turtles, slider turtles, water snakes, largemouth bass, several panfish, bullfrogs, toads, crayfish, and freshwater clams. This research seeks to identify the extent of contamination of organisms inhabiting the D-Area Ash Basins, and to help explore less expensive remediation alternatives. The goals of this research are to: (1) identify organisms that have elevated trace element levels and any associated morphological, physiological, and behavioral abnormalities; and (2) identify the amounts and routes of contaminants transferred into nearby terrestrial habitats by birds, mammals, and reptiles.

Elevated trace elements are associated with abnormalities in the following:

- Bullfrog tadpoles have oral and tail deformities, elevated metabolic costs, reduced swimming performance that result in increased risk of predation.

- Southern toads have abnormal hormone levels and reproductive behavior.

- Water snakes have higher body burdens of trace elements than do any other reptile or amphibian species documented in the literature.

- Slider turtles have reduced reproduction and transfer some trace elements (Se) to their eggs, and as a result some effects are experienced by developing embryos.

- Preliminary results on American alligators indicate that eggs from contaminated females have reduced viability compared to reference eggs from uncontaminated sites.

\section{Improved Quantitative Methods}

\section{Principal Investigator: Dr. Philip M. Dixon}

This program develops better statistical methods to analyze environmental and ecological data and communicate information on appropriate statistical methods to environmental scientists. Statistical analysis seeks to extract accurate conclusions from imprecise data and to quantify the uncertainty about those conclusions. Better statistical methods provide two benefits for environmental restoration and remediation: (1) more accurate conclusions from limited data and (2) less data is required to make appropriate decisions. This program also supports all the other research at SREL by providing statistical consulting and teaching short courses on statistical methods.

In the past year, this program also provided an independent evaluation to U.S. Department of Energy (DOE) of the statistical methods used by Westinghouse Savannah River Company (WSRC) to estimate procurement cost savings. In $\mathrm{FY}$ ' 98 our research focused on the estimation of $\mathrm{LC}_{50} \mathrm{~S}$, numbers that describe the sensitivity of a test species to a particular toxicant or combination of toxicants. $L C_{50} s$ are the foundation for many risk assessment methods. They can be estimated by exposing individuals to different concentrations of the toxicant. Traditional methods measure the number of living and dead animals at a fixed time and use a probit regression to estimate the $\mathrm{LC}_{50}$. An alternative is to record the actual time to death for those animals that die during the experiment and use a time-to-event method to estimate the $\mathrm{LC}_{50}$. We found that:

- Time-to-event methods provide more information about the $\mathrm{LC}_{50}$ than do traditional approaches.

- The improvement can be as much as $200 \%$, depending on how many animals die during the experiment.

- Equally precise estimates can be obtained from fewer animals if time-to-event methods are used.

\section{Phytoremediation: Plant-Based Technologies To Remediate Contaminated Soils And Plumes}

\section{Principal Investigators: Drs. Domy C. Adriano and Kenneth W. McLeod}

Contaminated soils at the SRS at other DOE sites contain a mixture of chemical pollutants, including pesticides, polychlorinated biphenyls (PCB), volatile organic compounds, metals, non-aqueous phase liquids (NAPL), and radionuclides. Most of these soils have dilute mixtures of wastes, whose phase behavior is dominated by poorly characterized chemical speciation. Current cleanup technologies are time consuming and expensive, are likely to create additional risk, and produce secondary waste. Therefore, it is necessary to develop technologies to reduce risk to the workers mitigating contaminated areas, minimize 
generation of collateral waste, and stabilize and contain contaminants in situ.

Plants can play a major role in remediating and rehabilitating degraded soils and plumes. Various plant species have been shown to stabilize, filter and/or extract excess nutrients, organic solvents, polycyclic aromatic hydrocarbons (PAHS), TNT residues, metals, and radionuclides. Plant roots also stabilize and improve soil structure decreasing erosion. Evapotranspiration by the plants will also minimize leaching of contaminants to the groundwater by reducing the amount of downward water movement. In the plant rhizosphere, a favorable environment exists for fungi and microorganisms to biodegrade toxic organic compounds. Plant-based remediation could be adopted in situations where contamination level is low, risk to the public is low, and where slower, low-cost cleanup can be substituted for an immediate and high-cost cleanup. These technologies can be especially suited when dealing with buried mixed wastes as plant roots absorb and transform/degrade both organic and inorganic constituents.

Maximum efficiency of phytoremediation depends on high absorption rates of the contaminants and high biomass production. Hyperaccumulator plant species have high absorption rates, but generally have low biomass. Plant species with high biomass are frequently sensitive to contaminants, which reduce biomass. Hence, optimum phytoremediation species will have a combination of uptake and biomass characteristics, neither of which will likely be maximum in itself, but the combination will extract significant amounts of the contaminant.

- Sesbania exaltata and S. vesicaria grew better ( 25 and 7 times, respectively) in soils saturated with coal pile runoff water than deionized water. The low $\mathrm{pH}$ coal pile runoff water alleviated the nutrient deficiency responsible for the chlorosis of plants in deionized water. Crotalaria juncea did not grow well due to excess soil water content.

- Unweathered fluidized gas desulfurization (FGD) material added to acidic soils at rates of 5 and $10 \%$ by weight decreased productivity of $S$. exaltata and Bidens sp. regardless of watering with deionized or coal pile runoff water. Germination of each species was not affected by the presence of FGD material or coal pile runoff water.

- Tolerance and uptake of heavy metals from soils containing up to $10 \% \mathrm{D}$-Area fly ash are currently being examined in Amaranthus tricolor, Chenopodium quinoa, Tagetes minuta, and Tithonia rotundifolia.

- Studies of nickel and uranium uptake by hybrid poplars (Populus sp.) growing in hydroponic culture have been initiated.
Risk Assessment of Mixed Waste: Synergistic Effects on Individuals and Populations

Principal Investigators: Drs. Justin D. Congdon and Thomas G. Hinton

Processing nuclear materials and other industrial activities such as steam and energy generation have produced mixed wastes at many sites on the Savannah River Site (SRS). Particular categories of wastes (i.e., radionuclides such as cesium and strontium, and toxic contaminants such as arsenic, cadmium, mercury, and selenium) can be associated with a specific processes or activities. However, once released into the environment, contaminants of various types and from many sources can result in complex mixtures that may create new environmental problems. Assessments of risk to non-humans associated with environmental contamination often focus on a single type of pollutants, but risk assessments based on a single stressor may be inadequate to describe the actual threats to individuals or populations. A 1994 review of risk assessment within the U.S. Department of Energy (DOE) Environmental Remediation Program, conducted by the National Academy of Sciences, stated: "If DOE or other stakeholders desire greater utility and less potential bias in the risk assessment process, then greater precision, more research, and more data are required [on] health effects of mixtures of wastes".

The goals of this research program are to: (1) identify sites where synergistic effects of mixed contaminants such as trace elements and radionuclides (cesium and strontium) pose problems for organisms; (2) identify which suites of contaminants are associated with morphological, physiological, behavioral and genetical abnormalities; and (3) identify the minimum amounts of mixed wastes that cause detectable abnormalities.

- We have adapted a molecular technique used to measure stable chromosomal aberrations in human atomic-bomb survivors to a biological dosimeter for determining ecological risks to non humans. Reciprocal translocations in exposed organism can be quantified by observing the fluorescent marker of translocated chromosomes. This tool is fundamental to determining what constitutes a "significant risk" in ecological risk analyses.

- A $0.2 \mathrm{Ci}{ }^{137} \mathrm{Cs}$ source designed specifically for our irradiation facility at Par Pond was field tested. This facility will allow us to examine synergistic effects of irradiation and heavy metal contamination on aquatic organisms. Based on this test the source has been returned to the vendor for modifications. 
Studies of the Fate and Effects of Nuclear Industrial Contaminants in Wildlife of the DOE Savannah River Site: Assessments of Ecological and Human Health Risks

Principal Investigators: Drs. I. Lehr Brisbin, jt. and Charles H. Jagoe

Concentrations of radiocesium $\left({ }^{137} \mathrm{Cs}\right)$ and non-nuclear contaminants (particularly mercury and other heavy metals) were determined in both free-living SRS wildlife and "sentinel animals" released into contaminated habitats. Sentinel animal studies, are undertaken to study factors controlling the uptake and concentration of these contaminants through controlled/manipulative experimentation. At the same time, assessments were made of biomarkers indicative of contaminant impacts upon these same animals, and this information is then related to the contaminant body-burdens of the same individuals. This work is focused mainly on species utilizing aquatic systems of the Savannah River Site (SRS), particularly the site's abandoned reactor cooling reservoirs (Par Pond, L-Lake, and Pond B). An emphasis is placed upon game species such as deer and hogs, that may be consumed by the public after being harvested on site. Concern is directed towards highly-mobile species (e.g., doves, waterfowl) that may become contaminated and then leave the site and serve as potential vectors of SRS contaminants to public hunting lands. This information is needed by DOE to make decisions concerning the long-term use of the SRS for recreational hunting by the public.

These studies are also designed to provide long-term baseline data of the kind required for both ecological and human health risk assessments for future SRS activities. Among these activities is the eventual need to consider draining one or more SRS reactor cooling reservoirs, as was proposed by the SRS River Water Shutdown Program, and the clean-up of contaminated waste sites under Federal Facilities Agreements (FFA). In order to produce the data that will be needed for risk assessments for these activities, this work combines the approaches used to study the basic ecology, behavior and movement (as studied through GIS technology), radioecology, molecular genetics, and ecotoxicology of each of the species being considered.

- Risk assessment based on mercury and ${ }^{137} \mathrm{Cs}$ concentrations in SRS alligators showed that mercury contamination and not radiocesium was the factor limiting the amount of meat that a member of the public could consume without exceeding recommended health guidelines.

- Analyses of radiocesium levels in more than 30,000 whitetailed-deer shot on annual SRS hunts show that the most contaminated deer are found in the relatively pristine northeastern sector of the site, and not in the immediate vicinity of known SRS leaks or spills.

- Over the past 3 decades, ${ }^{137} \mathrm{Cs}$ levels in SRS deer have not decreased at a rate any faster than would be expected on the basis of the physical decay of the isotope alone.

\section{Aquatic Invertebrates and Trophic Pathways for Contaminants in Pond 4, A Small Abandoned Cooling Reservoir on the SRS}

\author{
Principal Investigator: Dr. Barbara E. Taylor
}

Invertebrates constitute the bulk of the primary consumers in most aquatic systems and can thus play an important role in the trophic transfer of contaminants, such as methylmercury and radiocesium, to fish and other secondary consumers. The general structure of these pathways is known, but the specifics for small southeastern reservoirs are not. For example, about half of the production in shallow lakes typically occurs in the open water and about half in the littoral zone; we hypothesize that production in the littoral zone is relatively more important in southeastern reservoirs. In spring 1998, we began a 2-yr study of the invertebrates at Pond 4, an 11.4-ha reservoir on the canal leading from PReactor to Par Pond. The goals of the study are to quantify the abundances and biomasses of invertebrates and to evaluate which taxa and trophic pathways are potentially most important in transferring contaminants to fish. These results will also provide baseline data for the radiotracer study of contaminant movement planned for Pond 4 in spring 1999.

- Initial results from the spring and summer inventories indicate that the invertebrate assemblage is dominated by dipteran larvae. In spring, most of the dipteran larvae are benthic and littoral chironomids; in summer, planktonic Chaoborus larvae are also abundant.

- Studies comparing trophic pathways inferred from direct analyses of diets and from stable isotope ratios will begin in September. 


\section{RADIOECOLOGY}

Four decades of cold war production and distribution of radionuclides have resulted in releases of radiation into many ecosystems in the United States and Eurasia. The impetus for greater detailed information on kinetic processes, fate and effects on biology, and the relationship between absorbed dose and individual, population and community responses is provided by review of U.S. Department of Energy (DOE) by the National Academy of Sciences, by evaluation of revived missions and strategic plans for the DOE at the Savannah River Site and elsewhere, and by various state and federal agencies. The study of radiation in the environment has been a central tenet for SREL researchers. At one time the Savannah River Ecology Laboratory was named the Institute for Environmental Radiation. At this time, SREL remains as one of very few academic institutions deeply committed to the discipline of radioecology.

New directions for radioecological research at the Savannah River Ecology Laboratory address:

- Environmental distribution, uptake and transport of radioactive contaminants on the SRS: Meeting DOE needs for compliance and predictions of risk;

- Health effects to nonhumans from mixed wastes;

- Dose assessments for plants and animals exposed to environmental radiation

- Genetic changes in response to previous plant operations;

- Assessment of environmental problems associated with radionuclides in the environment;

- Development of bioindicators as a cost effective way for assessing risks; and

- International programs in radioecology. 
Dose Assessments for Plants and Animals Exposed to Environmental Radiation

Principal Investigators: Drs. Ronald K. Chesser, Thomas

G. Hinton, Michael H. Smith, and Gary L. Mills

$$
\text { trs. . }
$$

Determination of absorbed dose is a centcal tenet of radioecology, environmental and human health risk assessment, and regulatory compliance for mclean-up standards in habitats contaminated by radionuclides. The National Academy of Sciences recent review of the U.S. Department of Energy (DOE) risk analysis procedures stressed "greater precision, more research, and more data are required ... between ambient concentrations of contaminants in various environmental media and the doses critical to target organs." DOE is currently circulating proposed regulations for maximum allowable doses for aquatic fauna and flora and terrestrial plants (ten milliGray per day) and terrestrial animals (one milliGray per day). These regulations create an urgent need for accurate determination of dose accrued through internal and external sources of radiation. Few data exist for plants and animal dose rates to determine if regulatory compliance to these guidelines are being met on the Savannah River Site (SRS) or on other U.S. Department of Energy (DOE) and Department of Defense (DOD) complexes. Although "exposure" at many parts of the SRS has been well characterized, the relationship between exposure and absorbed dose is complex and robust methods for dose assessment are in need of development and testing. Accurate dose assessment is also critical for addressing biological phenomena associated with radiation by way of dose response relationships. These dose-response relationships will apply to a variety of end points including molecular change, DNA damage, cellular physiology, fertility, viability, and population/community dynamics.

Development of accurate methods for assigning absorbed dose could prove to be very cost-effective for clean-up activities on the SRS and other sites. Current tables and mathematical approaches for extrapolating dose from exposure values are usually overestimated. Knowledge of actual dose could exempt some regions from clean-up requirements or serve to downgrade polluted areas to lower priority or less stringent control measures. Monitoring of dosimetry in clean-up areas can quickly and accurately determine the progress of remediation efforts in reducing impacts to plants and animals in polluted regions.

- Based on internal dose models for radiocesium ( ${ }^{134,}$ $\left.{ }^{137} \mathrm{Cs}\right)$ and strontium $\left({ }^{90} \mathrm{Sr}+{ }^{90} \mathrm{Y}\right)$ and external thermoluminescent dosimeters, average dose rates for small mammals in the Chernobyl Exclusion Zone exceed the regulatory limits established by the IAEA and proposed by DOE (one milliGray per day). Dose rates to rodents were as high as 80 milliGray per day.

- An in situ method of predicting and testing dose rates has been developed and will be implemented for mammals at Chernobyl. This technique will assess the accuracy of dosimetric models. Knowledge of dose rates to non-human species is necessary for agencies such as DOE to determine if regulatory compliance is met.

- Dose reconstruction methods have been tested using chromosome translocation methods by chromosome painting in turtles. Results show that predictable amounts of chromosome translocations are produced by various amounts of radiation dose. These results enable accurate estimation of accumulated dose to non-human species.

\section{Environmental Distribution, Uptake, and Transport of} Radioactive Contaminants on the Savannah River Site: Meeting DOE Needs for Compliance and Predictions of Risk

Principal Investigators: Drs. Thomas G. Hinton, Justin D. Congdon, I. Lehr Brisbin, and John E. Pinder, III.

The need for "understanding the transport and fate of contaminants..." was specifically recommended as a priority by the National Academy of Sciences in their 1994 review of risk assessment within the DOE Environmental Remediation Program. With our current state of knowledge, however, it is difficult to understand the dynamics of the contaminants within ecological systems, and therefore to make predictions about future risks. To reduce the uncertainties, information is needed on site-specific rates of contaminant transfer among environmental compartments. Laboratory and field tracer experiments, combined with analytical techniques that identify contaminant speciation, will supply such information. This approach requires concurrent data on the ecological and geochemical aspects of the systems under study. Once the fluxes of contaminants within an ecosystem are quantified, the ability to make informed predictions, with reduced uncertainties, dramatically increases. The objectives of this research are: (1) to document current radioactive contaminant levels on the Savannah River Site; (2) to understand the mechanisms and processes that govern radionuclide transport; (3) accurately predict contaminant transport and fate; and (4) to determine current as well as future human and ecological risks from radioactive contamination.

- Plants growing on sediments contaminated $>35$ years ago in Par Pond initially had large concentration ratios indicating high ${ }^{137} \mathrm{Cs}$ uptake. In the next 3 yrs a rapid decline was observed. These results indicate that ${ }^{137} \mathrm{Cs}$ was initially bioavailable with reservoir drawdown and not tightly bound as was assumed. These results need to be considered in future reservoir water level management.

- The operationally defined bioavailable fraction from a common sequential extraction (SE) procedure was compared to biological availability. Plant uptake of ${ }^{137} \mathrm{Cs}$ and ${ }^{90} \mathrm{Sr}$. were compared between two locations in the Ukraine and at several field locations on the SRS. Results suggest that the SE procedure was useful for qualitative interpretations of biological availability but 
lacked sufficient rigor to be useful for quantitative predictions. The potential effective dose and health risk from Par Pond lake bed actinides via vegetable consumption using an EPA CERCLA Guidance Scenario involving a 30 y self-sufficient resident (U.S. EPA, 1991) were calculated. The effective anthropogenic actinide dose, when multiplied by the most current risk factor for fatal and non-fatal cancer, as well as severe hereditary effects, produces a lifetime risk of about $2 \times 10^{-6}$.

- Considerable effort was spent this year seeking approval to add a suite of tracers to Pond 4 on the SRS. State DHEC has yet to decide, although both human and ecological risk calculations indicate that radiation levels are below allowable limits. The project has the potential to supply DOE with the highest precision data to date on radiocontaminant migration rates within aquatic systems on the SRS.

\section{International Programs in Radioecology}

Principal Investigators: Drs. Ronald K. Chesser, Michael H. Smith, and Charles H. Jagoe

Despite the tragic nature of accidents at nuclear power plants such as Chernobyl, lessons learned from high levels of environmental radiation are invaluable for strategic planning in the event of future accidents, determining the effectiveness of cleanup technologies, and tracking the biological health risks associated with chronic exposure to radiation. The Radioecology Research Group at the Savannah River Ecology Laboratory (SREL) was established to discern the risk of radionuclides on the Savannah River Site (SRS) and to form an international center of excellence for the study of radiation in the environment. SREL scientists have been involved with research at Chernobyl and other sites in the Former Soviet Union (FSU) since 1992 and have fostered excellent working relationships with foreign scientists and administrators. Programs of study at foreign sites include characterization of radionuclide distributions, estimation of dose rates, determination of radionuclide inventories and dynamics, as well as biological effects to exposed organisms. Our efforts to strengthen working relationships with the scientists at Chernobyl have been realized by a recent invitation to establish a joint International Radioecology Laboratory within the confines of the Chernobyl Exclusion Zone.

Funds have been provided by U.S. Department of Energy (DOE)/Savannah River to equip the laboratory under the auspices of two separate agreements with the Ukrainian Government. The first is a Government to Government Agreement signed 22 July 1998 during the Gore-Kuchma summit. The second is a Lab to Lab agreement to be signed by the President of University of Georgia, Dr. Michael Adams, V.P. for Research, Dr. Joe Key, and the Director of the Chernobyl Center, Dr. Valery Glygalo in 1998. This laboratory will provide researchers from the FSU, Europe, and the United States with capabilities to perform field studies in the highly contaminated regions of the Chernobyl Zone and to analyze samples in a cost-efficient and coordinated manner. Activities at this laboratory will facilitate incorporation of methods, ideas, and technologies from international experts working in the field of environmental radiation, toxicology, biology and risk assessment. Importantly, the International Radioecology Laboratory (IRL) will provide SREL with an avenue to the variety of field sites necessary to discern the impacts and dynamics of radiation in highly contaminated sites, as well as access to experts in related studies from around the world. Scientists associated with the IRL will jointly plan, coordinate and conduct relevant studies in the Chernobyl Zones and data bases will be established and maintained to enable comprehensive analyses necessary for refinement of environmental and health risk assessments. Studies conducted at the IRL will have high relevance for the DOE as well as for Ukrainian concerns.

- A Government to Government Agreement establishing the International Radioecology Laboratory at Chernobyl, Ukraine was signed during the summit meeting between Vice President Gore and Ukrainian President Kuchma on 22 July 1998. DOE will provide funds, via SREL, to purchase equipment for the laboratory.

- A Lab-to-Lab Agreement has been written and tentatively approved. This agreement establishes the operational plans for the International Radioecology Laboratory. Ronald K. Chesser will travel to Ukraine in August 1998 to finalize details on this agreement.

- A facility for the International Radioecology Laboratory has been offered by Ukraine and will be inspected during the August visit.

- Manuscripts on dosimetry at Chernobyl, genetic markers, and soil radioactivity in the Chernobyl region were submitted and published.

- Chesser and coworkers have been invited to attend the second Chernobyl Conference at Slavutych, Ukraine in October 1998. Four papers will be presented covering DOE funded radioecology programs. The International Radioecology Laboratory will be announced and discussed.

\section{Genetic Changes in Response to Previous and Current Plant Operations}

Principal Investigators: Drs. Michael H. Smith, Ronald K. Chesser, Charles H. Jagoe, and I. L. Brisbin, Jr.

The U.S. Department of Energy (DOE) is currently circulating recommended radiation exposure guidelines for terrestrial organisms not to exceed one milliGray per day and for aquatic animals and terrestrial plants not to exceed ten milliGray per day. However, alterations of genetic material are possible at or below this level, especially in complex toxicant environments where radionuclides are but one component of the total toxicant burden. The goals of this research program are threefold: (1) to assess and quantify the effects of previous and current plant operations on the genetic structure and function of sentinel species; (2) to place this information into a sound ecological and evolutionary context; and (3) to use this information to help 
DOE in its environmental compliance and remediation efforts. To accomplish these goals we will develop exposure and effects biomarkers on selected sentinel species that will be useful in complex toxicant environments such as those found on the SRS. The basic unit of change is the sequence of the base pairs within DNA strands, however genetic damage and its effects can occur at scales that range from the gene, through the individual organism to populations and communities. We will use a variety of techniques to assess genetic damage and effects at several hierarchical scales. The principal techniques used will come from molecular, population and quantitative genetics, population ecology, radioecology, ecotoxicology, and risk assessment. We will use these techniques in both laboratory and field experiments as well as field surveys. The primary focus will be on flora and fauna from SRS sites, but we will also use organisms from elsewhere to provide an appropriate ecological context as well as to explore the generality of our findings (e.g., some of the same biomarkers may be compared in ecologically equivalent species from the SRS and Chernobyl). Thus our broader goal is to address applied problems with solutions that are based upon a solid theoretical and scientific basis.

- Microsatellite probes have been developed for alligators. These probes have been used to assay genetic variation and genotoxic damage in alligators from the SRS and other sites in South Carolina. Preliminary results indicate that eggs from a single nest may have multiple sires. Such information is valuable both as baseline ecological data and for refining ecological risk assessments.

- DNA strand breakage assays and biochemical assays of oxidative damage are currently underway. These techniques will allow increased sensitivity for both exposure and effects endpoints and thus will be of value for both classification of impacted sites and to increase the precision of risk-assessments. 


\section{RESEARCH SUPPORT PROGRAMS}

\section{Environmental Outreach and Education \\ Dr. J. Whitfield Gibbons}

The Division of Environmental Outreach was created at SREL during 1991. The program is designed to enhance SREL's overall mission of acquiring and communicating environmental knowledge and addresses U.S. Department of Energy's (DOE's) current focus on environmental issues. Since that time the Outreach program has reached hundreds of thousands of people. School groups enjoy field trips to the Laboratory's Conference Center and speakers from the Laboratory go into the schools, presenting messages of conservation, remediation, and environmental stewardship. Teachers are trained in methods of teaching ecology during workshops and leave with materials produced by the Outreach staff. Demand for speakers from SREL has grown so much that for the coming academic year one day a week will be devoted to teaching via Distance Learning. The Outreach program received recognition from the Council for the Advancement and Support of Education in 1996, with an Award of Excellence in its District III (Southeast) competition. The publications produced by this program have also garnered several awards for excellence, including one from the Society for Professional Journalists for the publication, "Biodiversity."

The Environmental Outreach Program presents talks on various environmental topics to local schools, civic groups, and other organizations, averaging four presentations per week and one tour per week. This program is responsible for managing the Laboratory's K-12 educational programs and for developing an enhanced public awareness of environmental issues on the SRS and of ongoing ecological research.

During the past year, SREL scheduled 208 lectures, 34 tours, 10 exhibits, and 27 workshops. This brought the total number of people reached to over 70,000. Topics for these presentations include biodiversity, animal adaptation, plants and wetlands, local ecosystems and conservation, classification, and careers in ecology and research.

Outreach programs include "Ecotalk," an opportunity for students to have nature brought into their classroom for a face-to-face lesson on a variety of live animals found in local habitats. "Ecologist for a Day" visits allow students to spend the day in the field gaining "hands-on" knowledge of the plants and animals of the unique Upper Three Runs Creek area. Participants get an opportunity to work with SREL researchers catching, marking, and measuring various species of reptiles, amphibians, small mammals, and invertebrates. Other presentations offered include tours of the lab and surrounding field sites, exhibits and workshops offered to the general public. Outreach also has distributed thousands of copies of educational products and materials nationwide to schools, organizations and the general public. Educational materials include two six-foot-long full color posters describing the importance of wetlands to amphibians along with teachers guides, and the "Outdoor Classroom Planning Guide." In 1997, SREL received a grant from the Donnelly Foundation to develop and present workshops based on this teachers guide for South Carolina Low Country educators. This year SREL also produced and distributed the full-color brochure "Snakes Of Georgia and South Carolina." This has proved to be an extremely successful educational product that reflects positively on DOE and the SRS. During the first month following publication, more than 12,000 copies of the booklet were distributed in response to requests from individuals and organizations in the two states.

The public relations program includes the distribution of news releases on a variety of topics to selected media affiliates, officials of DOE, and the University of Georgia. Included among these have been coverage of SREL research by CNN, U.S. News and World Report, Associated Press, BioScience, Earth Magazine, National Wildlife Magazine, National Public Radio, Our World, Atlanta Journal \& Constitution, Weekly Reader, L.A. Times, National Geographic, Audubon, Smithsonian Magazine, The Washington Post, and more. The program also has promoted various research projects through coverage in local and national media and has worked to enhance the laboratory's internal communications. Participation in the CSRA Environmental Consortium has provided opportunity to showcase SREL at Augusta's Fort Discovery Science Museum and has also provided opportunity for speakers from the lab to address groups at Fort Discovery. This program also has been responsible for planning and promoting special events, including tours for dignitaries and workshops for the general public. A 27-minute six-projector automated slide presentation about the history of the SRS and SREL research continues to be a regular part of SREL tours. Ongoing projects include an internal laboratory newsletter and a new newsletter for those outside the lab but interested in its work.

The Outreach program also has produced and distributes several publications: "Outdoor Classroom Planning Guide", "Biodiversity: Prospect \& Promise for the Savannah River Site and The National Environmental Research Park at Savannah River Site: Serving an Essential Mission for 25 Years", and "Snakes of Georgia and South Carolina." The Guide gives instructions for setting up a variety of outdoor classroom stations and outlines activities and investigations which teachers can use to guide students through hands-on learning experiences in natural settings. The biodiversity brochure highlights the site's vast natural resources, explains biodiversity in general and defines its various types, such as genetic diversity. This publication received the Best PR Magazine award from the Central Savannah River Area (CSRA) Chapter of the Society of Professional Journalists. The National Environmental Research Park (NERP) brochure highlights 25 years of research associated with the NERP program at the Savannah River Site. Also, a new set of full-color fact cards were produced this year, making the second set in the series.

SREL's latest publication, "Snakes of Georgia and South Carolina", serves as an identification guide to all snakes of 
the region as well as providing information on snake safety. Sponsors, including The State Museum (Columbia, SC), Fort Discovery (Augusta, GA), The Georgia Forestry Commission, the U.S. Forest Service, the Georgia Department of Natural Resources, and South Carolina Parks and Recreation, helped fund and distribute the booklet. SREL copies were distributed directly through the Public Relations and Outreach offices, some to participants in our educational programs, teachers, scout leaders, libraries, and hospital emergency rooms and others to the generaf public. Such a demand was created for the publication that a second printing is planned and a waiting list is being compiled.

The Pubic Relations office screens most inquiries from the press, directing reporters to the most helpful researchers for their stories. In addition, SREL-initiates press contacts, such as the annual Eco-Calendar, postings on Newswise and regular submissions to popular magazines, resulting in stories and new contacts with the media including stories in Reptile Life, The World \& I, Aiken County Magazine, and Environmental News Network.

\section{National Environmental Research Park Program \\ Dr. Nat B. Frazer}

The Savannah River National Environmental Research Park (NERP) is a protected outdoor laboratory for long-term research projects to study the environmental impacts of human activities. Because public access to U.S. Department of Energy (DOE) land is limited, environmental research projects can be carried out on the Savannah River Site (SRS) with a minimum of interference. The NERP is not simply a site to conduct research, but also should have programs which address the following general objectives: (1) development of methods to assess and monitor the environmental impact of human activities both quantitatively and continually; (2) development of methods to estimate or predict the environmental response to proposed or ongoing activities; and (3) demonstration of the impact of various activities on the environment and evaluation of methods to minimize adverse impacts. Pursuant to these objectives, it is necessary to supply basic data so that environmental decisions, standards, and monitoring programs can be developed upon a firm ecological base.

Previously, NERP initiatives changed annually as directed from DOElOHER in Washington D.C. However, the final disposition of the NERP program has fallen to local DOE sites because the program no longer is supported nationally by DOE's Office of Energy Research. In recent years, the SRS NERP program has been supported with funding from within the SREL budget. Each year, proposals were sought and reviewed by a committee composed of four SREL scientists (one from each research group), a representative from the Savannah River Natural Resource Management and Research Institute (SRI), and the NERP Director. This past year, no call for proposals was issued due to insufficient funding. Instead, the NERP Director and others attended a number of meetings to find potential sources of additional funding and to promote the NERP program and philosophy.
The SRS NERP program participated in several activities this past year. In August 1997, Dr, Nat Frazer, SRS NERP Director, was invited by the Ecological Society of America to participate in a panel on "The Role of the National Laboratories in Basic Ecological Research" at their annual meeting in Albuquerque, NM. This panel highlighted the involvement and importance of DOE lands in providing protected outdoor laboratories for scientists from government agencies, universities and private foundations to conduct research on human impacts on the natural environment. Panelists also included representatives from several of DOE's other NERPs and Dr. Eugene Odum, founder of SREL. Also at the ESA annual meeting in Albuquerque, the SRS NERP was invited to place a poster in the main registration hall. The poster by Gary Wein, Nat Frazer, Tracy Rea, Deno Karapatakis, and Felicia Munson, was entitled "Precious Legacies of the Cold War: DOE's National Environmental Research Parks" and presented information on all seven of DOE's NERPs.

In December 1997, Drs. Nat Frazer, Gary Wein, and Gary Mills attended the joint annual meeting in Washington, DC, of the Strategic Environmental Research and Development Program (SERDP), sponsored by the U.S. Environmental Protection Agency (EPA), DOE and U.S. Department of Defense (DOD), in cooperation with DOD's Environmental Security Technology Certification Program (ESTCP). The SRS NERP was represented by the following two invited poster presentations:

Nzengung, V. A. and G. L. Mills -- "Enhanced Degradation of Chlorinated DNAPL Contaminants Using Redox-Manipulated Aquifer Material and Iron-Bearing Clays"

Wein, G. R., R. R. Sharitz, J V. McArthur, K. W. McLeod, R. K. Kolka, and E. A. Nelson -- "Ecological Restoration of Wetlands in the Southeastern Coastal Plain: Technologies and Applications"

As a result of his participation in the ESA panel on use of DOE's national laboratories for ecological research, Dr. Frazer was invited to become a member of the Society's Public Affairs Committee. He attended the Committee's winter meeting in February 1998 and represented both the ESA and the SRS NERP during "Congressional Visits Day." During this meeting, representatives from over 50 scientific professional organizations and over 100 scientific and engineering firms were briefed by federal agencies and Congressional committees on science funding for the FY' 99 federal budget. Attendees also visited Congress to discuss in general the need for continued support of the sciences. Dr. Frazer had the opportunity to meet with Representative Graham and with Senator Hollings' Chief of Staff.

The SRS NERP Program also was responsible for several publications this past year.

Shearer, C. R. H. and N. B. Frazer. 1997. The National Environmental Research Park: A New Model for Federal Land Use. Natural Resources and Environment 12:46-51. (Published by the American Bar Association). This paper detailed a history and description of the NERP concept and 
provided arguments for the preservation of the NERP system.

Frazer, N. B. 1998. Preserving Natural Laboratories. Issues in Science and Technology, Spring, Volume 14, Number 3:16-18. (Published by the National Academy of Sciences). This paper was the result of an invitation to Dr. Frazer by the editor to respond to a previous paper on the NERP concept by Oak Ridge Scientists Virginal Dale and Pat Parr that had appeared in the winter issue of the journal.

Davis, C. E. and L. L. Janecek. 1997. DOE Research Set-Aside Areas of the Savannah River Site. (A publication of the Savannah River Site National Environmental Research Park Program, Publication number SRO-NERP-25). This book is a compilation of the history of the Set-Aside Program and detailed descriptions of each of the SRS NERP's 30 Set-Asides, complete with color maps of each area and color photographs of selected sites.

The NERP concept figured prominently in SRS site-wide activities related to Comprehensive Planning and Future Land Use this past year. The Future Use Plan (March 1998) states that (p. 4-1):

- SRS boundaries shall remain unchanged, an the land shall remain under the ownership of the federal government, consistent with the site's designation as a National Environmental Research Park.

- Natural resources shall be protected and managed with biodiversity being a primary goal. Disturbance of undeveloped land and valuable ecological habitats shall be minimized. Research set-asides should be maintained.

In addition, the Management Implementation Plan for the Assistant Manager for Science, Technology and Business Development states that: "With SREL Leadership, a multi-organizational team will develop a NERP marketing Plan to link environmental research to the NERP concept and issue the final by $9 / 30 / 98 . "$

To that end, a committee was formed in March 1998, consisting of representatives from the Savannah River Archaeological Research Program/South Carolina Institute of Archaeology and Anthropology, University of South Carolina, the Savannah River Natural Resources Management and Research Institute, the Environmental Sciences and Technology Department of the Savannah River Technology Center, the Savannah River Ecology Laboratory, and the Office of the Assistant Manager for Science, Technology and Business Development. This NERP Committee has begun work on 13 initiatives identified at their first meeting as activities that can be pursued with no increases in existing funding:

- Add information on the SRS NERP to existing GET and CAT training;

- Include SRS NERP information in all tours given on the SRS;

- Have the SRS Education Council incorporate information on the SRS NERP into all of their programs and materials;

- Develop an SRS NERP Fact Sheet for use with the above activities;

- Coordinate with Rick Ford on conducting a series of community leaders tours of the SRS;

- Write articles on the SRS NERP for local and regional publications such as Aiken County Magazine or the Augusta Chronicle;

- Cite the SRS NERP on all scientific publications produced by SRS personnel;

- Develop an SRS NERP logo;

- Develop SRS NERP slides and associated electronic media that can be used when talks are given at scientific and public meetings;

- Develop a 20-30 minute presentation (35mm slides and overheads) on the SRS NERP that can be used by anyone speaking to citizens' groups, etc.;

- Develop an SRS NERP display for the main "entrance" near the badging office;

- Explore the feasibility of partnering with the Ruth Patrick Science Center to promote the SRS NERP; and

- Explore the feasibility of using the SRS Emphasis Groups to promote the SRS NERP.

\section{DOE Research Set-Aside Areas}

\section{Charles E. Davis}

The purpose of the Set-Aside Program is to maintain areas on the Savannah River Site (SRS) that represent habitats which are unique or native to the region, offer protection to rare, threatened, and endangered biota that inhabit these areas, and provide sites on the SRS that are conducive to long-term ecological research. In addition, these relatively undisturbed areas serve as control sites for evaluations of the impacts of SRS site operations and forest management activities. Inclusion in the Set-Aside program ensures that these areas will be preserved and protected, aids in the maintenance of a high degree of biological diversity on the SRS, and enables U.S. Department of Energy (DOE)/Savannah River to meet the objectives of the National Environmental Research Park (NERP) Program.

This past year, a NERP document was published which details the history of the SRS Set-Aside Program and profiles each of the 30 DOE Research Set-Aside Areas. The profile of each Set-Aside contains a description and history of the Area, information on the vegetation communities and soil types found there, lists of sensitive flora and fauna documented from the Area, locator and resource composition maps, and lists of ecological research publications associated with each Area. This information also has been made available through SREL's Intranet Website. SREL's Geographic Information System (GIS) coverage for the Set-Aside Areas (Version 3)--which includes both boundary line and vegetation data, was formally released with its metadata documentation. Updates to these coverages are expected to be made annually as Set-Aside and timber stand boundary lines are verified and adjusted with Global Positioning Satellite (GPS) surveys. 
Cooperation between SREL and the Savannah River Natural Resource Management and Research Institute (SRI) continued this year as these the two organizations continued GIS verification of Set-Aside boundary lines that were concordant with the boundaries of planned SRI forest management activities. Approximately 5 miles of Set-Aside boundary line was GPSed by the SRI in the E. P. Odum Wetland and Oak Hickory \#2 Set-Asides during the summer of 1997; SREL verified the accuracy of these lines during the winter 1998 for line acceptance. Periodic inspections of Set-Aside boundary postings continue to be conducted by SREL where potential land-use conflicts are anticipated. Approximately 0.17 miles of boundary line in the University of Georgia Old Lab Site Set-Aside was modified to accommodate new educational laboratory facilities at the SRI. An SREL Site-Use Permit GIS was developed for active research projects in Set-Asides to provide maps for land use coordination and for conducting ecolitter evaluations which were begun this year as part of the ISO 14001 initiative.

SREL's Set-Aside research coordinator continued to participate as an ID team member in the SRI's prescription review process, which occurs during the development of natural resource management plans for Site timber compartments. This coordination and planning with the SRI is successful in verifying Set-Aside and timber stand boundary line concordance with GIS coverages, updating sensitive plant population surveys conducted in Set-Aside Areas, and in addressing potential conflicts with forestry activities adjacent to Set-Aside Areas. Pre-planning activities for the SRI's annual prescribed burning program continued: SREL and SRI agreed that permanent fireline will be established where necessary around Set-Aside areas. SREL and the SRI continue to cooperate in monitoring a potential pine beetle problem in the Kennedy Pond area of the E.P. Odum Wetland Set-Aside. Also this year, SREL has assembled a core team to develop a management plan for the Flamingo Bay Set-Aside. This core team is comprised of site experts in ecosystem processes and research associated with Flamingo Bay and will present a plan to DOE in October 1998.

SREL continued numerous long-term plant and animal studies in Set-Asides and initiated new studies this fiscal year, including: long term hydrological monitoring of Carolina bays, stream and bay insect population studies, expansion of ecotoxicology studies associated with Site ash basins using mammals, and several ecological studies on turtles. In addition, Carolina bay Set-Asides continue to be used as proxies in studies of the hydrology of man-made catchment basins; these studies will support future efforts to remediate such basins. New plant studies are examining the physiology of scrub oak species in the sandhills and resource heterogeneity of plants in old-fields. Groups other than SREL also continue to use the Set-Aside Areas. Westinghouse Savannah River Company (WSRC) is using shrews collected in Set-Aside Areas as control animals to test methods of evaluating remediation and restoration actions at DOE sites. SREL and SRI researchers continue to study coarse woody debris decomposition, softmast production in bottomland hardwood forests, the role of fleshy fruit production, consumption, and dispersal on promoting biological diversity. SREL and University of South Carolina -Archaeology continued to conduct archeological investigations around Set-Aside Carolina bays. Both the SRI and SREL continued to use Set-Aside Areas in education and outreach programs.

\section{Recent publications that used Set-Aside}

\section{Areas:}

Buhlmann, K.A. and J.W. Gibbons. 1997. Imperiled aquatic reptiles of the southeastern United States: historical review and current conservation status. p. 201-232. In Aquatic Fauna in Peril: The Southeastern Perspective, edited by George Benz and David Collins. Southeast Aquatic Research Institute, Lenz Design \& Communications. Decatur, Ga, 554p.

Davis, C.E. and L.L. Janecek. 1997. DOE Research Set-Aside Areas of the Savannah River Site. A publication of the Savannah River Ecology Laboratory National Environmental Research Park Program U.S. Department of Energy. SRO-NERP-25 Aiken, S.C.

Davis, C.E., J. Fondow, and D.J. Karapatakis. 1998. GIS Dataset of Set-Aside boundary line and vegetation communities -file SET-ASIDE-Version 3. SREL Metadata for GIS. Savannah River Ecology Laboratory, Aiken, S.C.

DeBiase, A.E. and B. Taylor. 1997. Aglaodiaptomus atomicus, a new species (Crustacea: Copepoda: Calanoida: Diaptomidae) from freshwater wetland ponds in South Carolina, U.S.A., and a redescription of $A$. saskatchewanensis (Wilson 1958). Proceedings of the Biological Society of Washington 110:569-580.

Demuth, J.P. and K.A. Buhlmann. 1997. Diet of the turtle Deirochelys reticularia on the Savannah River Site, South Carolina. Journal of Herpetology 31:450-453.

Gibbons, J.W. 1997. Measuring declines and natural variation in turtle populations: spatial lessons from long-term studies. p. 243-246. In International Conference on Conservation. Restoration, and Management of Tortoises and Turtles, edited by J.V. Abbema. New York Turtle and Tortoise Society. Purchase, NY.

Grant, J.A., M.J. Brooks, and B.E. Taylor. 1998. New constraints on the evolution of Carolina bays from ground-penetrating radar. Geomorphology 22:325-345.

Hinton, T.G., P.D. Fledderman, J.E. Lovich, J.D. Congdon, and J.W. Gibbons. 1997. Radiographic determination of fecundity: is the technique safe for developing turtle embryos? Chelonian Conservation and Biology 2:409-414.

Hopkins, W.A. 1997. Hormonal responses and trace element concentrations of souther toads, (Bufo terrestris), exposed to coal combustion wastes. Masters Thesis, Auburn University, Auburn Alabama. 83 pp.

Hopkins, W.A., M.T. Mendonca, and J.D. Congdon. 1997. Increased circulating levels of testosterone and corticosterone in southern toads, Bufo terrestris, 
exposed to coal combustion waste. General and Comparative Endocrinology 108:237-246.

Hopkins, W.A., M.T. Mendonca, C.L. Rowe, and J.D. Congdon. 1998. Elevated trace element concentrations in southern toads, Bufo terrestris, exposed to coal combustion waste. Archives of Environmental Contamination and Toxicology 35:325-329.

Jones, R.H. and R.R. Sharitz. 1998. Survival and growth of woody plant seedlings in the understorey of floodplain forest in South Carolina. Journal of Ecology (in press).

Leeper, D.A. and B.E. Taylor. 1998. Insect emergence from a South Carolina (USA) temporary wetland pond, with emphasis on the chironomidae (diptera). Journal of the North American Benthological Society 17:54-72.

Lide, R.F. 1997. When is a depression wetland a Carolina bay? Southeastern Geographer 37:90-98.

Newman, M.C. and R.H. Jagoe. 1998. Allozymes reflect the population-level effect of mercury: simulations of the mosquitofish (Gambusia holbrooki Girard) GPI-2 response. Ecotoxicology 7:141-150.

Peles, J.D. and G.W. Barrett. 1997. Assessment of metal uptake and genetic damage in small mammals inhabiting a fly ash basin. Bulletin of Environmental Contamination and Toxicology 59:279-284.

Plague, G.R. and J V. McArthur. 1998. Genetic diversity vs. geographic distribution of five congeneric caddisflies. Hydrobiologia 362:1-8.

Ryan, T.J. and R.D. Semlitsch. 1998. Intraspecific heterochrony and life history evolution: decoupling somatic and sexual development in a facultatively paedomorphic salamander. Proceedings of the National Academy of Sciences USA 95:5643-5648.

Sharitz, R.R. and C.A. Gresham. 1997. Pocosins and Carolina Bays. p. 343-377. In Southern Forested Wetlands Ecology and Management, edited by M.G. Messina and W.H. Conner. Lewis Publishers. Boca Raton.

Shearer, C.R.H. and N.B. Frazer. 1997. The National Environmental Research Park: A new model for federal land use. American Bar Association's Natural Resources and The Environment 12:46-51.

Snodgrass, J.W. 1997. Temporal and spatial dynamics of beaver-created patches as influenced by management practices in a south-eastern North American landscape. Journal of Applied Ecology 34:1043-1056.

Snodgrass, J.W. and G.K. Meffe. 1998. Influence of beavers on stream fish assemblages: effects of pond age and watershed position. Ecology 79:928-942.

Thomas, R.B., D.W. Beckman, K. Thompson, K.A. Buhlmann, J.W. Gibbons, and D.L. Moll.1997. Estimation of age for Trachemys scripta and Deirochelys reticularia by counting annual growth layers in claws. Copeia pp. 842-845.

Wohl, D.L. and J V. McArthur. 1998. Actinomycete-flora associated with submersed freshwater macrophytes. FEMS Microbiology Ecology
26:135-140.

\section{SREL Undergraduate and Graduate Education Program}

\section{Dr. J Vaun McArthur}

The objective of the SREL Education Program is to promote professional development and enhance environmental awareness among undergraduate and graduate students through research participation and training programs with emphasis on conducting ecological research important to the Savannah River Site Mission. Undergraduate and graduate student participants FY ' 98 are listed in Table 1.

The SREL Education Program has averaged 20 undergraduate students per year since 1968. These students, from over 100 different colleges and universities, have been co-authors on $120+$ peer reviewed research publications; more than 100 of these students have gone on to pursue careers in science. Since 1967, an average of six students a year have completed graduate studies at SREL and over 195 dissertations and theses have been written. The Undergraduate-Research Experience for Undergraduates, funded by the National Science Foundation, is in its first year and this year we sponsored 12 students. This is a three year grant from National Science Foundation.

Since 1985, our graduate students have won over 125 awards from regional, national, and international competitions at numerous professional societies and foundations. During the past year, our graduate students continued to compete successfully for various national and regional awards.

The SREL Education Program was also revised during FY '97. The new program will continue its commitment to support long-term graduate students previously supported by the old program. However, beginning in FY '98, the new program will entitle each SREL faculty member to only one graduate student funded through the Education Program. Additional graduate students may be supported by the faculty project budgets within the four research groups funded by the DOE Cooperative Agreement, or through outside grants awarded to faculty. All SREL graduate students to be supported by the DOE funds under SREL's Cooperative Agreement, will be reviewed by the Education Committee prior to admittance and be required to conduct research relevant to the U.S. Department of Energy (DOE) mission. This applies both to students supported through the Education Program as well as to students supported by projects within the four research groups funded by the SREL Cooperative Agreement with DOE. Students' progress towards completing degree requirements will be evaluated annually by the Education Committee, with time limits of up to five years for Ph.D. students and three years for Master's students. The Committee consists of five faculty members and is chaired by the Head of the Education Program, who reports to the Director. These changes will insure the continued success of the Education Program. 


\section{SREL Graduate Students Completing Degree Requirements}

Miller, Susan P. 1998. The Dynamics of the Grass-Mycorrhizal Fungi Association in Nutrient-Poor Wetland Ponds. Ph.D. University of Georgia, Athens, GA. Advisor: Rebecca Sharitz

Thompson, Andrew J. 1998. Vegetation Analysis and Classification of an Old-Growth Bottomland Hardwood Forest. M.S. University of Georgia, Athens, GA.

Advisor: Rebecca Sharitz

Bulhmann, Kurt. 1998. The Ecology, Life History, and Conservation of Deirochelys Reticularia, A Species of Freshwater Turtle Inhabiting Seasonally Fluctuating Wetlands. Ph.D. University of Georgia, Athens, GA. Advisor: J. Whitfield Gibbons 
TABLE 1. SREL Undergraduate and Graduate Student Program Participants Undergraduate Research Participation Program

Student

Jay Cumbee

Jocelyn Eikenburg

Larken Eulissâ

Amy Holbo

Amy Hudnor

Deidre Huff

Jeffery Mohr

Emily Moriarty

Jeremy Moyer

John Ray

Jackie Warlikowski

Caralyn Zehnder

Graduatent

Loretta Battaglia

Christopher Beck

Kurt Buhlmann

Mike Collyer

Adrienne Edwards

Mark Komoroski

Susan Miller

Julie Murray

Kelly Passek

Gordon Plague

Travis Ryan

Thomas Risch

Stephanie Schaeffer

Pat Shaw-Allen

Chris Tatara

Tracy Tostowaryk

Susan Turner

Debra Wohl

Rebecca Yeomans
Academic Institution

North Greenville College, SC

Marshall University, WV

North Carolina State University, NC

Truman State University, MO

Unity College, SC

Kentucky Wesleyan, KY

Furman University, SC

St. Mary's College, IN

University of South Carolina-Aiken, SC

Northwestern State University, IL

Armstrong State University, GA

Pennsylvania State University, PA

Faculty Advisor

I.L. Brisbin

K.W. McLeod

J. Seaman

M.H. Smith

B.S. Collins

C.H. Jagoe

J.W. Gibbons

J.W. Gibbons

D.C. Adriano

J.D. Congdon

I.L. Brisbin

J.D. Congdon

Faculty Advisor

R.R. Sharitz

J.D. Congdon

J.W. Gibbons

C. Stockwell

R.R. Sharitz

J.D. Congdon

R.R. Sharitz

I. L. Brisbin

L.J. Janecek

J V. McArthur

J. W. Gibbons

R.K. Chesser

P. Mulvey

C.H. Jagoe

C.H. Jagoe

T. G. Hinton

P. M. Dixon

J V. McArthur

J. D. Congdon

Ph.D. University of Georgia, GA

Research Program Graduate Students

Jennifer Brofft

David Henandez

Virginia Jin

Owen Kinney

Michelle Lakly

George Landman

Heather Lott

Mark Mills

Jim Novak

Denise Palleiko

Brandon Staub

Robert Thomas

Andrew Thompson

Laura Uhrich

Mark Wise

Alexander Wooten

Doug Wymer
M.S. University of Georgia, GA

Ph.D. University of Georgia, Ga

Ph.D. University of Georgia, GA

M.S. University of Georgia, GA

M.S. University of Georgia, GA

M.S. University of Georgia, GA

M.S. Texas A\& M, TX

Ph.D. University of Georgia, GA

Ph.D. University of Georgia, GA

Ph.D. University of Georgia, GA

M.S. University of Georgia, GA

$\mathrm{Ph} . \mathrm{D}$. University of Georgia, GA

M.S. University of Georgia, GA

Ph.D. University of Georgia, GA

Ph.D. University of Georgia, GA

M.S. American University, DC

M.S. Clemson University, SC
J V. McArthur

M.H. Smith

R.R. Sharitz

J.D. Congdon

J V. McArthur

R.R. Sharitz

G.L. Mills

J.W. Gibbons

M. H. Smith

R.R. Sharitz

J.D. Congdon

C.S. Romanek

R.R. Sharitz

R.R. Sharitz

J V. McArthur

R.R. Sharitz

J V. McArthur 


\section{Research Data Archive Activities}

\section{John Heuer and Gary Wein}

Responsible management of the research data holdings plays an important role in preserving SREL's corporate memory. Since 1989, SREL has been actively building a centralized repository of research datafiles and the associated "metadata" (data about data) necessary for these data to be fully accessible. The goals of SREL's Research Data Archive Activity are to avoid the inadvertent loss of data and to utilize advanced electronic computer/communication technology, including the use of computer networks and the Internet, to provide access to important data as efficiently as possible.

However, during FY' 98, the Research Data Archive Activity was adversely affected by laboratory downsizing. As a result, future activity will entail a significantly reduced central system development, management and oversight function. Various system models which emphasize a more distributed allocation of responsibilities are currently being developed. Likely candidates for a replacement system will heavily utilize WWW-based technology in an effort to reduce system and administrative overhead.

Inclusion of historical and new research information continued during FY '98 and the Central Archive Data Repository now has information which covers over 500 separate studies.

Requests for information from the archives included specific catalogs of studies for other SRS contractors and visiting researchers. The archive also served as a backup of information for laboratory personnel.

The searchable HTML-based catalog of studies managed in the Central Archive Data Repository was further developed but still remains under construction. When completed, this will permit anyone on site with a web-enabled computer to easily determine what studies in the SREL Central Repository match a particular area of interest.

The following studies were submitted for inclusion in the SREL research data archive system during FY" 98:

\section{Custodian Study}

Bertsch X-ray diffraction of oriented goethite samples

Brisbin Radiocesium in mourning doves on the SRS

Brisbin Metal concentrations in mourning doves from South Carolina

Congdon Parental investment in Kinosternid turtles from the Southeast

Congdon Energetic requirements for metamorphic climax in the southern toad

Congdon The effect of age and size at metamorphosis on performance and metabolic rate of southern toad metamorphs

Gibbons Prey preference in neonate brown water snakes

Hinton An evaluation of whole body potassium-40 content for estimating lean and fat mass in pigeons

Hinton Uptake of natural and anthropogenic actinides in vegetable crops grown on a contaminated lake bed

Hinton Variance partitioning as a guide for sampling and comparing spatial distributions of $\mathrm{Hg}$ and $\mathrm{Cs}^{137}$ in sediments

Hinton Operationally defined availability from sequential extraction compared to plant uptake of ${ }^{137} \mathrm{Cs}$ and ${ }^{90} \mathrm{Sr}$

Jagoe Mercury levels in prey fish of nestling wood storks in Georgia

Kennamer Mourning dove ${ }^{137} \mathrm{Cs}$ and metal levels during Par Pond drawdown

Kennamer Breeding characteristics of hooded mergansers on the SRS

Kennamer Composition of wood duck eggs in relation to egg size, laying sequence, and skipped days of laying

McLeod Uptake of boron by bottomland tree seedlings

McLeod Species selection and seedling establishment for restoration of bottomland forest

McLeod Flood and salinity stress of wetland woody species, buttonbush (Cephalanthus occidentalis) and swamp tupelo (Nyssa sylvatica var. biflora)

Meffe The influence of beaver ponds on the temporal dynamics of stream fish assemblages - Tims Branch and Meyers Branch, SRS

Meffe The influence of beaver pond age, watershed position, and environment on stream fish assemblage

Mulvey Population research on an endangered pupfish

Mulvey Life history traits among four recently established populations of western mosquitofish

Newman Oral availability of methyl mercury to channel catfish

Pinder Water levels in 56 Carolina bays and similar depression wetlands at the Savannah River Site: March, 1995 - July, 1997

Pinder An examination of deforestation, reforestation and forest fragmentation on the upper coastal plain of South Carolina and Georgia

Smith Effects of landscape spatial structure on movement patterns of the hispid cotton rat

Taylor Biodiversity of ground-layer macroarachnid (Araneae and Opiliones) assemblages from four piedmont floodplain habitats

Taylor Rainbow Bay insect emergence

Taylor

Whicker Diversity and life history variation among ground-dwelling linyphiidae (Araneae)

Temporal trends of radiocesium in an abandoned reactor cooling reservoir 


\section{Environmental Health and Safety Program \\ Warren J. Safter and Donald R. Mosser}

The fiscal year began with the adoption of the work-smart safety and environmental standards which resulted from SREL's participation in U.S. Department of Energy (DOE's) Necessary and Sufficient process. As many of these new standards were implemented, internal policies and procedures were modified to reflect the new requirements. Many of the former DOE requirements were replaced by University of Georgia policies. SREL's safety and environmental training program were similarly modified.

Throughout the year, SREL's role in regard to site-wide programs was redefined. In June, SREL submitted its Radiation Protection Plan (RPP) to DOE/SR for their review prior to submission to DOE/HQ. The RPP will permit SREL to operate its radiation program in accordance with established university research laboratory protocol rather than that of a nuclear facility.

Concurrent with the implementation of SREL's work-smart standards, the safety and environmental program suffered a decrease in personnel due to budget constraints. As a result, many of the former services were eliminated or reduced in scope. Other programmatic responsibilities were transferred to existing SREL personnel.

In May, 1998, SREL discovered a Resource Conservation and Recovery Act infraction in one of its satellite hazardous waste accumulation areas and reported such to the South Carolina Department of Health and Environmental Control (SCDHEC). In June, SREL received a Notice of Violation for this infraction. Corrective measures to eliminate the chances of a similar occurrence were implemented immediately. In July, 1998, SREL received a warning letter from SCDHEC. However, no penalty was assessed for this infraction.

This past summer, SREL received ISO 14001 certification. The ISO 14001 program required SREL to establish policies to assure environmental responsibility and continual improvement as good stewards of the environment. A January, 1998 assessment of SREL's progress was encouraging. Policies and goal-setting activities were completed in June.

\section{Quality Assurance Program Gary R. Wein}

SREL has continued to maintain a formal, U.S. Department of Energy (DOE)-approved quality assurance (QA) program based on the requirements of DOE Order $5700.6 \mathrm{C}$. The program is unique within the DOE complex in that it was created directly from the requirements of that DOE Order, rather than being adapted from earlier, nuclear facility QA requirements. The program is devoted to assuring the continuing quality of SREL research and is managed by a dedicated QA program coordinator.
The SREL QA program has been the subject of a number of conference papers and journal articles. SREL has been directly involved in the development of a number of national consensus standards related to research quality assurance and quality management.

A booklet providing guidance to SREL researchers titled "SREL Good Research Practices" was written and distributed to SREL research personnel. This booklet discusses research concepts and context, research logistics; and the conduct of research. Copies are available from Gary Wein.

\section{SPECIAL}

\section{ACCOMPLISHMENTS OF FACULTY, STAFF, STUDENTS AND ADMINISTRATION}

\section{Noteworthy Events and Special Activities}

\section{Scientific Review}

A Scientific Review of the Savannah River Ecology Laboratory was conducted by the Savannah River U.S. Department of Energy (DOE) on April 21-24, 1997. The nine reviewers were selected from the academic community, other DOE Laboratories, DOE Headquarters, and industry. The review was conducted by interviewing the DOE representatives on the SRS and by the SREL faculty presenting posters which summarized recent scientific findings. The final report of the Scientific Review of the Savannah River Ecology Laboratory was received on August 1, 1997. "The panel was highly supportive and complimentary of SREL's excellent research record, its response to the needs of the SRS, and its accomplishments in education and outreach over an extended period of time." The panel made several general recommendations that would help SREL to respond to the changing needs and missions of the DOE.

- SREL needs a long-term strategic plan that goes well beyond the recent reorganization of its administrative structure.

- SRS management needs to clarify the respective role of SREL, SRTC, and USFS on the SRS.

- SREL must carefully consider its staffing in order to address gaps that may exist in context of it's strategic plans.

- Improve communication and interaction with Westinghouse Savannah River Company's Environmental Advisory Council.

- Continue to seek outside funding support for research at SREL.

- SREL should consider establishing a permanent advisory committee. 
- The panel supports efforts to improve the national visibility of the National Environmental Research Park at the SRS.

\section{New Faculty}

In order to compensate for changing DOE mission needs and faculty attrition, a search was initiated in the fall of 1997 for two new faculty members in two of the following four areas: environmental microbiology, surface water hydrology, molecular ecological genetics, and/or environmental microbiology. A total of eight candidates were invited to present seminars and meet with the SREL faculty in the spring of 1998 . Based on these interviews, positions have been offered to Dr. Travis Glenn of the University of South Carolina and Dr. Betsy Sutherland from Brookhaven National Laboratory. Dr. Glenn has accepted one position and will start with SREL in the fall of 1998. Negotiations are ongoing with Dr. Sutherland.

\section{Strategic Planning}

The Savannah River Site (SRS) began a comprehensive planning process in FY ' 98 during which representatives of all site organizations drafted a new sitewide Strategic Plan. Issued in December, 1997, this new plan integrates Site planning, budget, and management in a manner consistent with the new U.S. Department of Energy Strategic Plan. As part of this process, SREL is represented on a sitewide Planning Board, which drafted the SRS Strategic Plan and coordinates planning activities of all Site organizations, as well as on an Executive Board, which sets policy for the SRS. Following completion of the SRS Strategic Plan, all U.S. Department of Energy (DOE) organizations on the SRS prepared individual Management Implementation Plans (MIP) which integrate their activities with the SRS Strategic Plan. SREL worked with its DOE-SR line organization, the Office of Science, Technology, and Business Development (OSTBD), during the development of its MIP to ensure that SREL contributes to the successful attainment of the longterm goals of the OSTBD and the SRS. The OSTBD Management Implementation Plan contains several performance measures for which SREL will be held accountable during the next fiscal year.

SREL research faculty have revised their individual research programs in light of the issuance of the SRS Strategic Plan and the OSTBD Management Implementation Plan. Research plans that tie directly to the goals and objectives of the SRS Strategic Plan were developed by individual SREL faculty and were provided to OSTBD to communicate to SREL's DOE customer the relevance and importance of the scientific research being conducted by SREL with DOE funding. These research plans detail specific performance measures and deliverables for which SREL researchers will be held accountable. Individual research plans will be revised on an annual basis so that adjustments in research programs may be made to ensure that site-wide objectives continue to be met.

The second phase of the sitewide comprehensive planning process involved the development of a Future Use Plan for the Site. The SRS Future Use Plan, completed in March, 1998, represents one component of a larger SRS Comprehensive Plan, still under development. Specifically, the Future Use Plan establishes a planning baseline and path forward so that SRS management can make effective futureuse decisions. Other components of the Comprehensive Plan are currently under development and include an Infrastructure Plan, a Cultural Resources Plan, and a Natural Resources Management Plan. SREL is contributing as appropriate to the development of these additional plans.

\section{Distance Learning Facility}

In the past year, SREL's Distance Learning Facility (DLF) has been completed and placed into operation. During that time over 300 hours of academic programming and 116 hours of meetings, conferences and lectures were offered over the Georgia Statewide Academic and Medical System (GSAMS) network. For example, students at SREL have attended classes in Soil Chemistry, Statistics, and Advanced Topics in Geology; and personnel for SRS have attended classroom instructions aiding them in preparing to take the professional engineers examination. Additionally, faculty has been involved in teaching ecology to high schools students and sponsored a series of lecture titled "Ecologists on Ecology." These lectures were presented over GSAMS to nine high schools reaching over 600 students.

- Construction and final finishing work on the $4000 \mathrm{ft}^{2}$ four-classroom Distance Learning Facility was completed. Furniture for two non-DLF capable classrooms was purchased. This allows SREL to use these additional rooms as traditional classrooms or for small meetings.

- A DLF degree program offering a Master of Science Degree from Georgia Institute of Technology in Health Physics will be offered in 1998.

- Georgia Tech's refresher course titled Fundamentals of Engineering, a program to prepare engineers for the Fundamentals of Engineering Exam, was offered in the winter of 1998 and again in the fall.

- Dr. Christopher S. Romanek continued to offer a program via the DLF to discuss "Life on Mars." He reached $15 \mathrm{~K}-12$ Georgia schools, a total of 33 schools since he started the program in 1997.

- Distance Learning Facility programs under development include:

Master of Science Degree in Environmental Toxicology from the UGA

Master of Business Administration from Georgia Southern University

Series of talks on "The Chemistry of Ecology" from SREL

Electrical Standards from Georgia Institute of Technology

Principles of Ergonomics from Georgia Institute of Technology

OSHA Guide to Industrial Hygiene from Georgia Institute of Technology

Documentation for ISO 14000 \& Environmental Management Systems from Georgia Institute of Technology

The Management Representative Workshop for ISO 9000 , ISO 14000, and QS-9000 Systems from Georgia Institute of Technology

Auditing for ISO 14000 \& Environmental Systems from Georgia Institute of Technology

Machinery and Machine Guarding Standards from Georgia Institute of Technology 
Professional Engineers Problem Practice Workshop from Southern Polytechnic State University

Technical and Precision Writing from Southern Polytechnic State University

\section{ISO 14001}

This past summer, SREL received ISO 14001 certification along with other SRS contractors. The program required SREL to establish policies to assure environmental responsibility and continual improvement as good stewards of the environment. A January, 1998 assessment of SREL's progress was encouraging. Policies and goal-setting activities were completed in June. SREL is a contributing member of the ISO 14001 Management Team.

\section{Internet and Intranet}

The SREL continues to develop and maintain its two web pages, an Internet homepage (www.uga.edu/srel) and an Intranet homepage (skippy.srs.gov). These homepages includes information about the current Laboratory research programs and a description of faculty and facilities. In addition, newspaper releases are available. The Intranet homepage is only accessible to the SRS and is for both communication of SREL research and administration purposes.

\section{Awards, Honors, and Outstanding Recognition}

Dr. Domy C. Adriano received the Most Outstanding Alumnus Award presented by San Ildefonso College during its Golden Jubilee Homecoming, Tanaz, Rizal, The Philippines.

Dr. Domy C. Adriano, Chairman of the International Executive Committee for the "Biogeochemistry of Trace Elements", continues to provide sustained leadership as he helps to develop a highly successful 5 th conference which is to be held in Vienna, Austria in July of 1999.

Dr. Paul M. Bertsch was selected a Fellow of the American Society of Agronomy. He was also appointed Chair of a research review panel evaluating the EPA's Hazardous Substance Research Center and nominated for the Advanced Photon Source Users Organization Steering Committee.

Dr. Paul M. Bertsch and others were awarded $\$ 1,250,000$ by the U.S. DOE 1997 Environmental Management Science Program for a proposal titled "Mineral Surface Processes Responsible for the Decreased Retardation (or Enhanced Mobilization) of ${ }^{137} \mathrm{Cs}$ from HLW Tank Discharges."

Drs. I. Lehr Brisbin, Jr. and Charles H. Jagoe received new funding from the Department of Energy in FY' 98 to begin a two-year study on the foraging habits of eagles on the Savannah River Site and the potential impacts to eagles of contaminants in their prey. The information will provide basic knowledge about eagle behavior and data for use in ecological risk assessments.
Dr. I. Lehr Brisbin, Jr. was co-organizer and co-chair of the symposium "Advances in Molecular Genetics and Taxonomy; Technologies for Ornithology, Conservation Biology and Zoo/Avicultural Needs," held in conjunction with the annual meetings of the American Ornithologists' Union, Minneapolis, MN.

Dr. Ronald K. Chesser was the winner of the Westinghouse Vice President's Award (for humanitarian efforts to Ukraine and saving over $\$ 1,000,000$ for Westinghouse Savannah River Company). He is also a member of the Chernobyl Research Council.

The University of Georgia, DOE, and the government of Ukraine are close to signing an agreement to establish an International Center for Radioecology at Chernobyl within the Chernobyl Exclusion Zone. The agreement represents the culmination of much effort on the part of Dr. Ronald K. Chesser and others at SREL and elsewhere.

Dr. Beverly S. Collins became the editor-in-chief of the oldest botanical journal in the Western Hemisphere, the Journal of the Torrey Botanical Society.

Dr. Philip M. Dixon was elected publications chair for the Environmental Section of the American Statistical Association

Graduate student Adrienne L. Edwards received a Massachusetts Threatened and Endangered Species Program Grant for the research project, "Population genetics of two rare herbaceous perennials found in isolated wetlands: Sagittaria isoetiformis and $S$. teres." She also received the South Carolina Aquatic Plant Management Society Research Grant, for the research project "Population dynamics of a rare wetland perennial in Carolina bays."

Andrew Bridges, a former SREL student, has won the Eugene P. Odum Award for the paper "Temporal variation in anuran calling behavior: implications for calling surveys and population assessment" co-authored with Michael E. Dorcas, a current SREL post-doc. This award is presented by the Southeastern Chapter of the Ecological Society of America for the best ecological paper presented by a student.

Dr. Shingara Sandhu, Director of Research and Grants Coordinator at Claflin College, received an award from SREL in recognition for his nearly 20 years of productive collaboration with the lab. He was also recognized for his work with minority students and administration of educational programs, which were supported by funds from the DOE's Historically Black Colleges and Universities.

Brant Ulsh, (Ph.D. candidate) won a student travel award to present research findings detailing the response of turtle fibroblasts to acute irradiation at the National meeting of the Radiation Research Society in Louisville, KY. 


\section{Funded Grants}

P.I.:

Project Title:

Funding Agency:

Funding Level:

P.I.:

Project Title:

Funding Agency:

Funding Level:

P.I.:

Project Title:

Funding Agency:

Funding Level:

P.I.:

Project Title:

Funding Agency:

Funding Level:

P.I.:

Project Title:

Funding Agency:

Funding Level:

P.I.:

Project Title:

Funding Agency:

Funding Level:

P.I.:

Project Title:

Funding Agency:

Funding Level:

P.I.:

Project Title:

Funding Agency:

Funding Level:

P.I.:

Project Title:

Funding Agency:

Funding Level:

P.I.:

Project Title:

Funding Agency:

Funding Level:
Dr. Domy C. Adriano

Coal Ash Utilization for Soil Amendment to Enhance Water relations and Turf Growth

Electric Power Research Institute

$\$ 60,000$

Dr. Paul M. Bertsch/Dr. Doug B. Hunter

Metals Management in Low Effluent Pulp and Paper Mills

Georgia Consortium for Technological Competitiveness in Pulp and Paper

$\$ 60,000(30 \mathrm{~K} / \mathrm{yr}$. for $2 \mathrm{yrs}$.)

Dr. Paul M. Bertsch/Dr. John C. Seaman

Environmental Impact of Stable Colloidal Suspensions in Soils and Geologic Materials

Westinghouse Savannah River Company

$\$ 35,000$

Dr. Paul M. Bertsch

Mineral Surface Processes Responsible for the Decreased Retardation (or Enhanced Mobilization) of ${ }^{137} \mathrm{Cs}$ from High Level Waste Tank Discharges

U.S. DOE Office of Energy Research and Environmental Management, Pacific Northwest National Laboratory

$\$ 225,000(75 \mathrm{~K} / \mathrm{yr}$. for $3 \mathrm{yrs}$.)

\section{Dr. Paul M. Bertsch}

Microbial Reduction and Immobilization of Uranium in Fe (III)- and Mn (IV)- Containing Sediments

DOE Natural and Accelerated Bioremediation Program (NABIR), Pacific Northwest National Laboratory

$\$ 135,000$

Drs. Paul M. Bertsch, Doug Hunter, Brian Teppen

Support for the Advanced Analytical Center for Environmental Sciences

U.S. DOE Office of Energy Research and Environmental Management

$\$ 800,000$

Dr. I. Lehr Brisbin, Jr.

The Use of Birds as Bioindicators of Environmental Contamination Stress

Rutgers University Consortium for Risk Evaluation with Stakeholder Participation (CRESP)

$\$ 14,000$

Dr. I. Lehr Brisbin, Jr.

A Study of the Foraging Ecology of Wood Storks (Mycteria americana) Utilizing Georgia's Coastal Zone

Georgia Department of Natural Resources

$\$ 19,947$

Dr. I. Lehr Brisbin, Jr.

Movement Patterns of Wood Storks in the Georgia Coastal Zone

U.S. Fish and Wildlife Service

$\$ 23,992$

Dr. I. Lehr Brisbin, Jr.

Description and Use of Wood Stork Roost Sites in Georgia's Coastal Zone

U.S. Fish and Wildlife Service

$\$ 7,965$ 
P.I.:

Project Title:

Funding Agency:

Funding Level:

P.I.:

Project Title:

Funding Agency:

Funding Level:

P.I.:

Project Title:

Funding Agency:

Funding Level:

\section{P.I.:}

Project Title:

Funding Agency:

Funding Level:

P.I.:

Project Title:

Funding Agency:

Funding Level:

P.I.:

Project Title:

Funding Agency:

Funding Level:

P.I.:

Project Title:

Funding Agency:

Funding Level:

P.I.:

Project Title:

Funding Agency:

Funding Level:

P.I.:

Project Title:

Funding Agency:

Funding Level:

P.I.:

Project Title:

Funding Agency:

Funding Level:

P.I.:

Project Title:

Funding Agency:

Funding Level:
Dr. I. Lehr Brisbin, Jr. and Karen Gaines

Development of a Spatially-Explicit Model Using a Geographic Information System (GIS) in Support of Research Efforts to Investigate the Cause of Eagle and Waterfowl Deaths at the DeGray's Lake Reservoir

Arkansas Game and Fish Commission

$\$ 54,566$

Drs. I. Lehr Brisbin, Jr. and Charles H. Jagoe

Determination of Mercury Concentrations in Wood Stork (Mycteria americana) Nestlings in Georgia

Georgia Department of Natural Resources

$\$ 14,993$

Dr. I. Lehr Brisbin, Jr.

Aerial Surveys of Aquatic Bird Use of Managed Wetlands in the Vicinity of the Augusta

Bush Field Municipal Airport

City of Augusta and the Ecosystems Institute, Inc.

$\$ 10,298$

Dr. Beverly S. Collins

Herbivory and Plant Interactions in Bottomland Hardwood Experimental Gaps

U.S. Department of Agriculture

$\$ 142,117$

Dr. Philip M. Dixon

Travel Support for Radionuclide Sampling Committee

International Commission on Radiation Units and Measures

$\$ 5,000$

Dr. Philip M. Dixon

Travel Support for International Workshop on Time-to-Event Models

Society for Toxicology and Environmental Chemistry (UK)

$\$ 500$

Dr. J. Whitfield Gibbons

Herpetofaunal Survey of the Woodbury Tract in South Carolina

Audubon Society, National Fish and Wildlife Foundation, and National Council for Air and Stream Improvement

$\$ 240,000$ (3 yrs.)

Dr. J. Whitfield Gibbons

Use of Automated Recording Systems for Detection of Anurans

Ontario Hydro Technologies

$\$ 12,000$

Dr. J. Whitfield Gibbons

Workshops for Low Country Teachers

Donnelly Foundation

$\$ 15,000$ (2 yrs.)

Dr. J. Whitfield Gibbons

Effects of Crab Trapping on Diamondback Terrapins

South Carolina Department of Natural Resources

$\$ 5,000$ (2 yrs.)

Dr. J. Whitfield Gibbons

Effects of Contaminants on Turtles

Rutgers University Consortium for Risk Evaluation with Stakeholder Participation (CRESP)

$\$ 39,000$ 
P.I.:

Project Title:

Funding Agency:

Funding Level:

P.I.:

Project Title:

Funding Agency:

Funding Level:

P.I.:

Project Title:

Funding Agency:

Funding Level:

\section{P.I.:}

Project Title:

Funding Agency: Funding Level:

P.I.:

Project Title:

Funding Agency:

Funding Level:

P.I.:

Project Title:

Funding Agency: Funding Level:

P.I.:

Project Title:

Funding Agency:

Funding Level:

P.I.:

Project Title:

Funding Agency:

Funding Level:

P.I.:

Project Title:

Funding Agency:

Funding Level:

P.I.:

Project Title:

Funding Agency:

Funding Level:

\section{P.I.:}

Project Title:

Funding Agency:

Funding Level:
Dr. J. Whitfield Gibbons

Determination of the Impact of Crab Trapping on Diamondback Terrapins

Wildlife Conservation Society

$\$ 7,925(2$ yrs. $)$

\section{Dr. J. Whitfield Gibbons}

Determination of Gopher Tortoise Population Levels at the Tillman Sand Ridge

South Carolina Department of Natural Resources

$\$ 15,000$

Dr. Thomas Hinton

Determining Significant Endpoints for: Ecological Risk Analyses

DOE (EMSP)

$\$ 897,666$

Drs. Lisa A. Donovan, Christopher Peterson, and Kenneth W. McLeod

Role of Fire Management in Species Composition, Distribution of Soil Resources, and Plant Resource Status for Fall-Line Sandhill Oak Communities

Savannah River Site (SRS) National Environmental Research Park (NERP)

$\$ 19,800$

Dr. Kenneth W. McLeod

Wetland Treatability Study to Assess Potential Removal of Metals from A-01 Outfall

Savannah River Technology Center

$\$ 51,118$

Dr. Kenneth W. McLeod

Photosynthetic Potential of Advanced Regeneration Following Four Silvicultural

Regeneration Methods

U.S. Department of Agriculture/Southern Research Station

$\$ 20,000$

Dr. Ken McLeod

Assessment of Harvesting Bottomland Hardwood Sites on Plant Competition and Ecosystem Processes

U.S. Department of Agriculture/Savannah River Resource Management and Research Institute

$\$ 25,000$

Dr. John D. Peles

Effects of Landscape Structure and Vegetation Pattern on the Movement of Small Mammals within an Experimental Landscape

United States Department of Agriculture - Savannah River Resource Management and

Research Institute

$\$ 39,782$

Dr. Michael E. Dorcas

Coarse Woody Debris

Savannah River Resource Management and Research Institute

$\$ 15,000$

Drs. John E. Pinder, III and Gary R. Wein

Development of a 1996 Habitat Map for the Savannah River Site

Westinghouse Savannah River Corporation - Environmental Restoration

$\$ 53,998$

Dr. Christopher S. Romanek

Stable Isotopic Analysis of Secondary Minerals in ALH84001

Office of Space Science

$\$ 45,000$ 
P.I.:

Project Title:

Funding Agency:

Funding Level:

P.I.:

Project Title:

Funding Agency:

Funding Level:

\section{P.I.:}

Project Title:

Funding Agency: Funding Level:

P.I.:

Project Title:

Funding Agency:

Funding Level:

\section{P.I.:}

Project Title:

Funding Agency: Funding Level:

P.I.:

Project Title:

Funding Agency:

Funding Level:

\section{Dr. Christopher S. Romanek}

Three-Oxygen Isotope Analysis at the LEAL Lab, Johnson Space Center

National Aeronautics and Space Administration (NASA)

$\$ 25,000$

\section{Dr. John C. Seaman}

Physicochemical and Mineralogical Control of Solute and Colloidal Tracer Migration: A Field Study

Education, Research, and Development Association

$\$ 135,000$

\section{Dr. Rebecca R. Sharitz}

Wetland Database-Guided Field Verification of Vegetative Communities in the Congaree Swamp National Monument

U.S. Department of the Interior National Park Service

$\$ 35,949$

Dr. Rebecca R. Sharitz

Ecological Risk Assessment

Rutgers University Consortium for Risk Evaluation with Stakeholder Participation (CRESP) $\$ 4,000$

\section{Dr. Barbara E. Taylor and Evelyn Gaiser}

Doctoral Dissertation: Paleolimnological Reconstruction of Holocene Environments in Wetland Ponds of the Upper Atlantic Coastal Plain

National Science Foundation

$\$ 5,570$

\section{Dr. Brian J. Teppen}

Molecular Simulation of Adsorption at the Clay Mineral/Aqueous Solution Interface U.S. Department of Agriculture National Research Initiative Competitive Grants Program $\$ 233,000$ 


\section{PUBLICATIONS}

\section{Books Published and in Press}

Adriano, D.C., Z.S. Chen, S.S. Yang, and I.K. Iskandar. 1997. Biogeochemistry of Trace Metals. Science Reviews, Northwood, England. 432 p.

Iskandar, I.K. and D.C. Adriano. 1997. Remediation of Soils Contaminated with Metals. Science Reviews, Northwood, England. 255 p.

Gibbons, J. Whitfield and A. R. Gibbons. Ecoviews: Snakes, Snails, and Environmental Tales. 1998. University of Alabama Press, Tuscaloosa, Alabama. 168 p.

Newman, M.C. and Carl L. Strojan. 1998. Risk Assessment. Logic and Measurement. Ann Arbor Press, Chelsea, Michigan. $352 \mathrm{p}$.

\section{Journal Articles and Book Chapters Published}

\section{SREL}

Reprint No.

2180 McLeod, K.W. and T.G. Ciravolo. 1997. Differential sensitivity of Nyssa aquatica and Taxodium distichum seedlings grown in fly ash amended sand. Wetlands 17:330-335

2181 Peles, J.D. and G.W. Barrett. 1997. Assessment of metal uptake and genetic damage in small mammals inhabiting a fly ash basin. Bulletin of Environmental Contamination and Toxicology 59:279-284.

2182 Howard, R.D., R.S. Moorman, and H.H. Whiteman. 1997. Differential effects of mate competition and mate choice on eastern tiger salamanders. Animal Behaviour 53:1345-1356.

2183 Pederson, N.A., R.H. Jones, and R.R. Sharitz. 1997. Age structure and possible origins of old Pinus taeda stands in a floodplain forest. Journal of the Torrey Botanical Society $124: 111-123$

2184 Ford, R.G., P.M. Bertsch, and K.J. Farley. 1997. Changes in transition and heavy metal partitioning during hydrous iron oxide aging. Environmental Science and Technology 31:2028-2033.

2185 Burger, J., J. Sanchez, J.W. Gibbons, and M. Gochfeld. 1997. Risk perception, federal spending, and the Savannah River Site: attitudes of hunters and fishermen. Risk Analysis 17:313-320.

Dudka, S. and D.C. Adriano. 1997. Environmental impacts of metal ore mining and processing: a review. Journal of Environmental Quality 26:590-602.

2187 Dosskey, M.G. and P.M. Bertsch. 1997. Transport of dissolved organic matter through a sandy forest soil. Soil Science Society of America Journal 61:920-927. subsaturated conditions. Soil Science Society of America Journal 61:746-752.

Pinder, J.E., III, G.C. Kroh, J.D. White, and A.M.B May. 1997. The relationships between vegetation type and topography in Lassen Volcanic National Park. Plant Ecology 131:17-29.

2190 Kennamer, R.A., S.K. Alsum, and S.V. Colwell. 1997 Composition of wood duck eggs in relation to egg size, laying sequence, and skipped days of laying. The Auk 114:479-487.

2191 Lide, R.F. 1997. When is a depression wetland a Carolina bay? Southeastern Geographer 37:90-98.

Brisbin, I.L., K.F. Gaines, C.H. Jagoe, and P.A Consolie. 1997. Population studies of American alligators (Alligator mississippiensis) inhabiting a reservoir: responses to long-term drawdown and subsequent refill. p. 446-477. In Proceedings of the 13th Working Meeting of the IUCN/SSC Crocodile Specialist Group, IUCN-The World Conservation Union. Gland, Switzerland

Dobson, F.S., R.K. Chesser, J.L. Hoogland, D.W. Sugg, and D.W. Foltz. 1997. Do black-tailed prairie dogs minimize inbreeding? Evolution 51:970-978.

van Loben Sels, R.C., J.D. Congdon, and J.T. Austin 1997. Life history and ecology of the Sonoran mud turtle (Kinosternon sonoriense) in Southeastern Arizona: a preliminary report. Chelonian Conservation and Biology 2:338-344.

2195 Hinton, T.G., P. Fledderman, J. Lovich, J.D. Congdon, and J.W. Gibbons. 1997. Radiographic determination of fecundity: is the technique safe for developing turtle embryos? Chelonian Conservation and Biology 2:409414

2196 Gates, W.P., D.B. Hunter, P.R. Nuessle, and P.M. Bertsch. 1997. A time resolved XANES study of an organo-clay redox system. Journal of Physique IV France 7:785-787.

2197 Lingenfelser, S.K., C.E. Dallas, C.H. Jagoe, R.K. Chesser, M.H. Smith and M. Lomakin. 1997. Variation in blood cell DNA in Carassius carassius from ponds near Chernobyl, Ukraine. Ecotoxicology 6:187-203.

2198 Tucker, A.D., S.R. Yeomans, and J.W. Gibbons. 1997. Shell strength of mud snails (Ilyanassa obsoleta) may deter foraging by diamondback terrapins (Malaclemys terrapin). American Midland Naturalist 138:224-229.

2199 Buhlmann, K.A. and J.C. Mitchell. 1997. Ecological notes on the amphibians and reptiles of the naval surface warfare center, Dahlgren Laboratory, King George County, Virginia. Banisteria 9:45-51.

Hunter, D.B., P.M. Bertsch, K.M. Kemner, and S.B. Clark. 1997. Distribution and chemical speciation of metals and metalloids in biota collected from contaminated environments by spatially resolved XRF, XANES, and EXAFS. Journal de Physique IV France 7:767-771.

2201 Bertsch, P.M., D.B. Hunter, P.R. Nuessie, and S.B. Clark. 1997. Molecular characterization of contaminants in soils by spatially resolved XRF \& XANES spectroscopy. Journal de Physique IV France 7:817-818. 

Effects of a partial drawdown on the dynamics of ${ }^{137} \mathrm{Cs}$ in an abandoned reactor cooling reservoir. p. 193-202. In Freshwater and Estuarine Radioecology, edited by G. Desmet et al. Elsevier Science.

Hinton, T.G. and F.W. Whicker. 1997. A screening model approach to determine probable impacts to fish from historic releases of radionuclides. p. 425-432. In Freshwater and Estuarine Radioecology, edited by G. Desmet et al. Elsevier Science.

2204 Scribner, K.T., M.H. Smith, and R.K. Chesser. 1997. Spatial and temporal variability of microgeographic genetic structure in white-tailed deer. Journal of Mammalogy 78:744-755.

Chlopecka, A. and D.C. Adriano. 1997. Zinc uptake by plants on amended polluted soils. p. 527-532. In XII International Plant Nutrition Colloquium, edited by T.A. et. al. Kluwer Academic Publishers. Tokyo, Japan.

2206 Demuth, J.P. and K.A. Buhlmann. 1997. Diet of the turtle Deirochelys reticularia on the Savannah River Site, South Carolina. Journal of Herpetology 31:450453.

Plummer, M.V. 1997. Population ecology of green snakes (Opheodrys aestivus) revisited. Herpetological Monographs 11:102-123.

2208 Snodgrass, J.W. 1997. Temporal and spatial dynamics of beaver-created patches as influenced by management practices in a south-eastern North American landscape. Journal of Applied Ecology 34:1043-1056.

2209 Lingenfelser, S.K., C.E. Dallas, C.H. Jagoe, M.H. Smith, I.L. Brisbin, and R.K. Chesser. 1997. Variation in DNA content of blood cells of largemouth bass from contaminated and uncontaminated waters. Environmental Toxicology and Chemistry 16:21362143.

2210 Seaman, J.C., P.M. Bertsch, and R.N. Strom. 1997. Characterization of colloids mobilized from southeastern coastal plain sediments. Environmental Science and Technology 31:2782-2790.

2211 Kemner, K.M., D.B. Hunter, E.J. Gall, P.M. Bertsch, J.P. Kirkland, and W.T. Elam. 1997. Molecular characterization of $\mathrm{Cr}$ phases in contaminated soils by $\mathrm{Cr}$ and Fe EXAFS: A tool for evaluating chemical remediation strategies. Journal de Physique IV France $7: 811-812$

2212 Kemner, K.M., D.B. Hunter, B.M. Bertsch, J.P. Kirkland, and W.T. Elam. 1997. Determination of site specific binding environments of surface sorbed cesium on clay minerals by Cs-EXAFS. Journal de Physique IV France 7:777-779.

2213 Mitchell, J.C., S.C. Rinehart, J.F. Pagels, K.A. Buhlmann, and C.A. Pague. 1997. Factors influencing amphibian and small mammal assemblages in central Appalachian forests. Forest Ecology and Management 96:65-76.

2214 Niewiarowski, P.H., J.D. Congdon, A.E. Dunham, L.J. Vitt, and D.W. Tinkle. 1997. Tales of lizard tails: effects of tail autotomy on subsequent survival and growth of free-ranging hatchling Uta stansburiana. Canadian Journal of Zoology 75:542-548.

Brim-Box, J.D. Williams, and R.S. Butler. 1997. Conservation genetics of North American freshwater mussels Amblema and Megalonaias. Conservation Biology 11:868-878.

2216 Jagoe, R.H. and M.C. Newman. 1997. Bootstrap estimation of community NOEC values. Ecotoxicology 6:293-306

2217 Sharitz, R.R. and C.A. Gresham. 1997. Pocosins and Carolina Bays. p. 343-377. In Southern Forested Wetlands Ecology and Management, edited by M.G Messina and W.H. Conner. Lewis Publishers. Boca Raton.

2218 Beck, C.W. and B.D. Watts. 1997. The effect of cover and food space use by wintering song sparrows and field sparrows. Canadian Journal of Zoology 75:1636-1641.

2219 Hopkins, W.A., M.T. Mendonca, and J.D. Congdon. 1997. Increased circulating levels of testosterone and corticosterone in southern toads, Bufo terrestris, exposed to coal combustion waste. General and Comparative Endocrinology 108:237-246.

Ford, R.G., P.M. Bertsch, and J.C. Seaman. 1997. Goethite morphologies investigated via X-ray diffraction of oriented samples. Clays and Clay Minerals 45:769. 772.

2221 Connor, D.M., T.G. Hinton, and C.M. Bell. 1997. Variance partitioning as a guide for sampling and comparing spatial distributions of $\mathrm{Hg}$ and ${ }^{137} \mathrm{Cs}$ in sediments. Science of the Total Environment 206:167. 176.

2222 Jagoe, C.H. and T.A. Haines. 1996. Changes in gill morphology of Atlantic salmon (Salmo salar) smolts due to addition of acid and aluminum to stream water Environmental Pollution 97:137-146.

Beck, C.W. 1997. Effect of changes in resource level on age and size at metamorphosis in Hyla squirella. Oecologia 112:187-192.

2224 Tatara, C.P., M.C. Newman, J.T. McCloskey, and P.L Williams. 1997. Predicting relative metal toxicity with ion characteristics: Caenorhabditis elegans LC50. Aquatic Toxicology 39:279-290.

2225 Weeks, S.C. and G.K. Meffe. 1997. "Grandfather Effects" on offspring size in the eastern mosquitofish, Gambusia holbrooki. Copeia 4:869-874.

2226 Hernandez-Martich, J.D. and M.H. Smith. 1997 Downstream gene flow and genetic structure of Gambusia holbrooki (eastem mosquitofish) populations. Heredity 79:295-301.

May, A.M.B., J.E. Pinder, III, and G.C. Kroh. 1997. A comparison of Landsat Thematic Mapper and SPOT multi-spectral imagery for the classification of shrub and meadow vegetation in northern California, U.S.A International Journal of Remote Sensing 18:3719-3728.

Seigel, R.A., C.A. Sheil, and J.S. Doody. 1998. Changes in a population of an endangered rattlesnake Sistrurus catenatus following a severe flood. Biological Conservation 83:127-131. 
Stephens, J.A., F.W. Whicker, and S.A. Ibrahim. 1998. self-burial of Aristida tuberculosa florets. Journal of the Torrey Botanical Society 124:306-311. atomicus, a new species (Crustacea: Copepoda: Calanoida: Diaptomidae) from freshwater wetland ponds in South Carolina, U.S.A., and a redescription of $A$. saskatchewanensis (Wilson 1958). Proceedings of the Biological Society of Washington 110:569-580.

2231 Foré, S.A., J.L. Vankat, and R.L. Schaefer. 1997 Temporal variation in the woody understory of an oldgrowth Fagus-Acer forest and implications for overstory recruitment. Journal of Vegetation Science 8:607-614.

2232 Jones, R.H., B.P. Allen, and R.R. Sharitz. 1997. Why do early-emerging tree seedlings have survival advantages? A test using Acer rubrum (Aceraceae). American Journal of Botany 84:1714-1718.

2233 Chlopecka, A. and D.C. Adriano. 1997. Influence of zeolite, apatite and $\mathrm{Fe}$-oxide on $\mathrm{Cd}$ and $\mathrm{Pb}$ uptake by crops. The Science of the Total Environment 207:195206.

2234 Mohler, H.J., F.W. Whicker, and T.G. Hinton. 1997 Temporal trends of ${ }^{137} \mathrm{Cs}$ in an abandoned reactor cooling reservoir. Journal of Environmental Radioactivity 37:251-268.

2235 Draney, M.L. 1997. Ground-layer spiders (Araneae) of a Georgia piedmont floodplain agroecosystem: species list, phenology and habitat selection. The Journal of Arachnology 25:333-351.

2236 De Steven, D. and R.R. Sharitz. 1997. Differentia recovery of a deepwater swamp forest across a gradient of disturbance intensity. Wetlands 17:476-484.

2237 Conner, W.H., K.W. McLeod, and J.K. McCarron. 1997. Flooding and salinity effects on growth and survival of four common forested wetland species. Wetlands Ecology and Management 5:99-109.

2238 Martin, H.W. and D.I. Kaplan. 1998. Temporal changes in cadmium, thallium, and vanadium mobility in soil and phytoavailability under field conditions. Water, Air, and Soil Pollution 101:399-410.

2239 Rowe, C.L., O.M. Kinney, R.D. Nagel, and J.D. Congdon. 1998. Elevated maintenance costs in an anuran (Rana catesbeiana) exposed to a mixture of trace elements during the embryonic and early larval periods. Physiological Zoology 71:27-35.

2240 FitzSimmons, N.N., S.W. Buskirk, and M.H. Smith. 1997. Genetic changes in reintroduced Rocky Mountain bighorn sheep populations. Journal of Wildlife Management 61:863-872.

2241 Gessaman, J.A., R.D. Nagle, and J.D. Congdon. 1998 Evaluation of the cyclopropane absorption method of measuring avian body fat. The Auk 115:175-187.

2242 Thomas, R.B., D.W. Beckman, K. Thompson, K.A Buhlmann, J.W. Gibbons, and D.L. Moll. 1997 Estimation of age for Trachemys scripta and Deirochelys reticularia by counting annual growth layers in claws. Copeia 4:842-845.

Sorption of $\mathrm{Cs}$ and $\mathrm{Sr}$ to profundal sediments of a Savannah River Site reservoir. Joumal of Environmental Radioactivity 38:293-315.

2244 Teppen, B.J., C.H. Yu, D.M. Miller, and L. Schafer 1998. Molecular dynamics simulations of sorption of organic compounds at the clay mineral/aqueous solution interface. Journal of Computational Chemistry 19:144153.

Fedynich, A.M., A.L.Bryan, Jr., and M.T. Harris. 1998 Hematozoa in the endangered wood stork from Georgia. Journal of Wildlife Diseases 34:165-167.

Whiteman, H.H. 1997. Maintenance of polymorphism promoted by sex-specific fitness payoffs. Evolution 51:2039-2044.

2247 Rowe, C.L., O.M. Kinney, and J.D. Congdon. 1998 Oral deformities in tadpoles of the bullfrog (Rana catesbeiana) caused by conditions in a polluted habitat. Copeia 1:244-246.

Beck, C.W. 1998. Mode of fertilization and parental care in anurans. Animal Behavior 55:439-449.

2249 Voelz, N.J., JV. McArthur, and R.B. Rader. 1998 Upstream mobility of the Asiatic clam corbicula fluminea: identifying potential dispersal agents. Journal of Freshwater Ecology 13:39-45.

Spitz, F., G. Valet, and I.L. Brisbin, Jr. 1998. Variation in body mass of wild boars from Southern France. Journal of Mammalogy 79:251-259.

Burger, J., R.A. Kennamer, I.L. Brisbin, Jr., and $M$ Gochfeld. 1997. Metal Levels in mourning doves from South Carolina: potential hazards to doves and hunters. Environmental Research 75:173-186.

2252 Jagoe, C.H., R.K. Chesser, M.H. Smith, M.D. Lomakin, S.K. Lingenfelser, and C.E. Dallas. 1997. Levels of cesium, mercury and lead in fish, and cesium in pond sediments in an inhabited region of the Ukraine near Chernobyl. Environmental Pollution 98:223-232.

2253 Dorcas, M.E. and C.R. Peterson. 1998. Daily body temperature variation in free-ranging rubber boas. Herpetologica 54:88-103.

2254 Close, L.M. and R.A. Seigel. 1997. Differences in body size among populations of red-eared sliders (Trachemys scripta elegans) subjected to different levels of harvesting. Chelonian Conservation and Biology 2:563566.

2255 Gibbons, J.W. 1997. Measuring declines and natural variation in turtle populations: spatial lessons from longterm studies. p. 243-246. In International Conference on Conservation. Restoration, and Management of Tortoises and Turtles, edited by J.V. Abbema. New York Turtle and Tortoise Society. Purchase, NY.

2256 Buhlmann, K.A., J.C. Mitchell, and M.G. Rollins. 1997 New approaches for the conservation of bog turtles, Clemmys muhlenbergii, in Virginia. p. 359-363. In International Conference on Conservation. Restoration. and Management of Tortoises and Turtles, edited by J.V. Abbema. New York Turtle and Tortoise Society. Purchase, NY 
Frazer, N.B. 1997. Turtle conservation and halfway technology: What is the problem? p. 422-425. In International Conference on Conservation. Restoration, and Management of Tortoises and Turtles. edited by J.V. Abbema. New York Turtle and Tortoise Society. Purchase, NY.

2258 Gariboldi, J., C. Jagoe, and A.L.J. Bryan. 1998. Dietary exposure to mercury in nestling wood storks (Mycteria americana) in Georgia. Archives of Environmental Contamination and Toxicology 34:398-405.

2259 Snodgrass, J.W. and G.K. Meffe. 1998. Influence of beavers on stream fish assemblages: effects of pond age and watershed position. Ecology 79:928-942.

2260 Kennamer, R.A., I.L. Brisbin, C.D. McCreedy, and J. Burger. 1998. Radiocesium in mouming doves: effects of a contaminated reservoir drawdown and risk to human consumers. Journal of Wildlife Management 62:497-508

2261 Buhlmann, K.A. and J.W. Gibbons. 1997. Imperiled aquatic reptiles of the Southeastern United States: historical review and current conservation status. p. 201232. In Conference on Aquatic Fauna in Peril: The Southeastern Perspective, edited by George Benz and David Collins. Southeast Aquatic Research Institute, Lenz Design \& Communications. Decatur, GA., 554p.

2262 Shearer, C.R.H. and N.B. Frazer. 1997. The National Environmental Research Park: A new model for federal land use. American Bar Association's Natural Resources and The Environment 12:46-51.

Seaman, J.C. 1998. Retardation of fluorobenzoate tracers in highly weathered soil and groundwater systems. Soil Science Society of America Journal 62:354-361

Dixon, P.M., A.R. Olsen, and B.M. Kahn. 1998. Measuring trends in ecological resources. Ecological Applications 8:225-227.

Philippi, T., P.M. Dixon, and B.E. Taylor. 1998. Detecting trends in species composition. Ecological Applications 8:300-308.

Leeper, D.A. and B.E. Taylor. 1998. Insect emergence from a South Carolina (USA) temporary wetland pond, with emphasis on the chironomidae (diptera). Journal of the North American Benthological Society 17:54-72.

Plague, G., J.B. Wallace, and J.W. Grubaugh. 1998. Linkages between trophic variability and distribution of Pteronarcys spp. (Plecoptera: Pteronarcyidae) along a stream continuum. American. Midland Naturalist 139:224-234.

Ryan, T.J. and R.D. Semlitsch. 1998. Intraspecific heterochrony and life history evolution: decoupling somatic and sexual development in a facultatively paedomorphic salamander. Proceedings of the National Academy of Sciences USA 95:5643-5648.
Assessment: Logic and Measurement, edited by $M$ Newman and C. Strojan. Ann Arbor Press, Inc. Chelsea, Michigan.

Plague, G.R. and JV. McArthur. 1998. Genetic diversity vs. geographic distribution of five congeneric caddisflies. Hydrobiologia 362:1-8.

Brisbin, I.L. 1998. Comment on the proposed conservation of usage of 15 mammal specific names based on wild species, which are antedated by or contemporary with those based on domestic animals. Bulletin of Zoological Nomenclature 55:43-46.

2273 McDonald, L.M., V.P. Evangelou, and P.M. Bertsch. 1998. The potential role of sediment mineralogy in regulating aluminum concentrations in lakewater. Water, Air and Soil Pollution 104:41-55.

2274 Lovich, J.E. and J.W. Gibbons. 1997. Conservation of covert species: protecting species we don't even know. p. 426-429. In Proceedings from An International Conference on Conservation. Restoration. and Management of Tortoises and Turtles, New York Turtle and Tortoise Society.

2275 Newman, M.C. and R.H. Jagoe. 1998. Allozymes reflect the population-level effect of mercury: simulations of the mosquitofish (Gambusia holbrooki Girard) GPI-2 response. Ecotoxicology 7:141-150. 
APPENDIX. Figure 1. Organizational Chart, Savannah River Ecology Laboratory

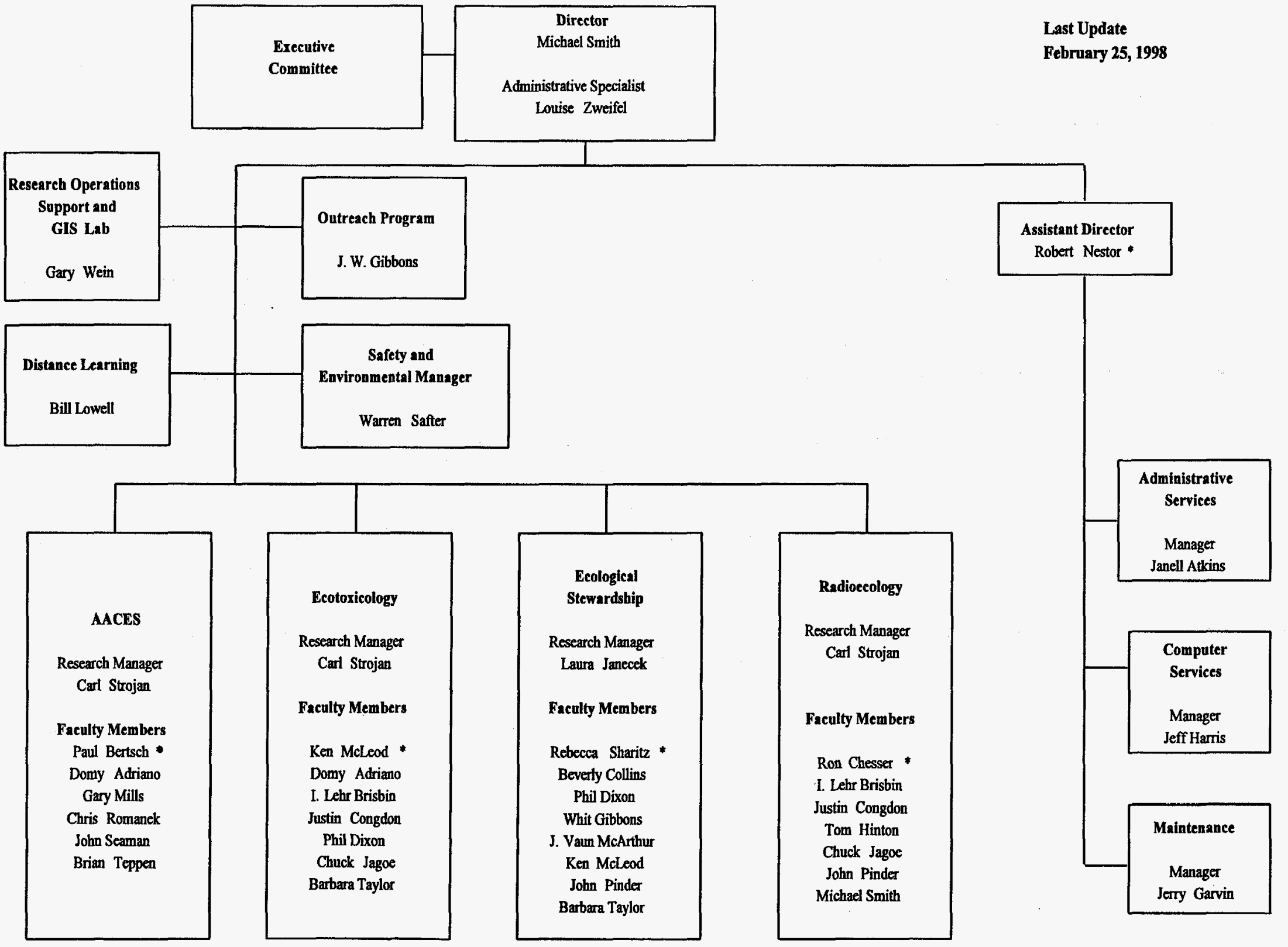

